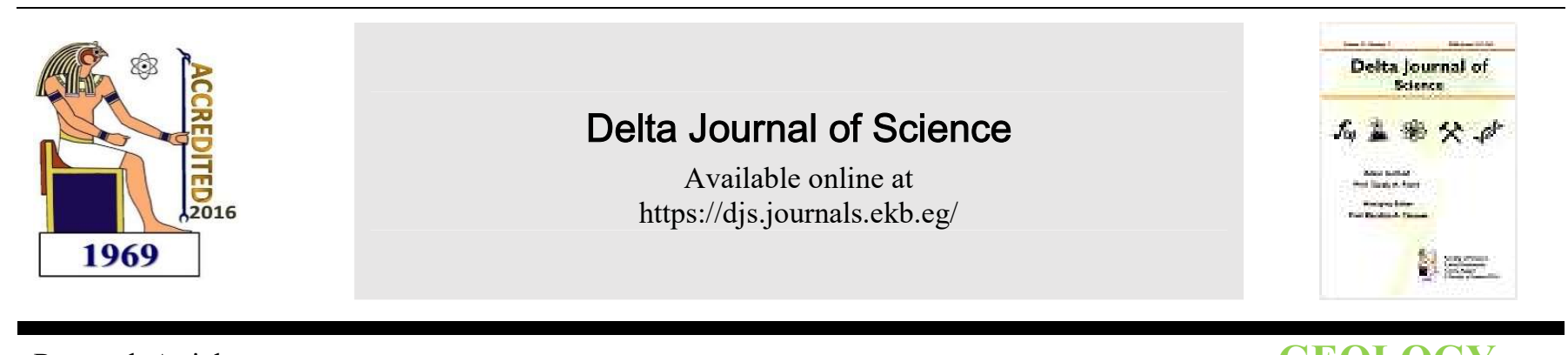

Research Article

\title{
Stratigraical studies on the Upper Cretaceous - Lower Eocenerocks in Central Eastern Desert, Egypt
}

Khalil H, Fathy M. S., Abdeldayem A. L. and Ghobara O. A.

Geology Department, Faculty of Science, Tanta University, Tanta, Egypt hamzakhalil2002@yahoo.com

\section{Abstract}

An attempt has been made to construct the lithostratigraphic and biostratigraphic characters of the Upper Cretaceous-Lower Eocene rocks exposed at Gebel Duwi and Gebel Atshan sections, central Eastern Desert. Lithostratigraphically, the studied succession arerepresented by four rock units arranged from base to top as: Dakhla, Tarawan, Esna and Thebes formations.

Detailed study of planktonic foraminifera and calcareous nannofossils has led to the recognition of forty five calcareous nannofossil and thirty one planktonic foraminiferal species. Twelve planktonic foraminiferal biozones, Racemiguembelina fructicosa Subzone (CF4), Pseudoguembelina hariaensis Subzone (CF3), Pseudoguembelina palpebra Subzone (CF2), Parasubbotina pseudobulloides Subzone (P1a), Praemurica uncinata Zone (P2), Morozovella angulata Zone (P3, subdivided intoIgorina pusilla Subzone P3a and Igorina albeari Subzone P3b), Globanomalina pseudomenardii Zone (P4), Morozovella velascoensis Zone (P5), Acarinina sibaiyaensis Zone (E1), Pseudohastigerina wilcoxensis-Morozovella velascoensis Zone (E2), Morozovella marginodentata Zone (E3) and Morozovella Formosa Zone (E4) have been recognized as well as twelve calcareous nannofossil biozones; Micula murus Subzone (CC25c), Micula prinsii Subzone (CC26b), Cruciplacolithus tenuis Zone (NP2), Ellipsolithus macellus Zone (NP4), Fasciculithus tympaniformis Zone (NP5), Heliolithus kleinpellii Zone (NP6), Discoastermohleri Zone (NP7/ NP8), Discoaster multiradiatus Zone (NP9), Tribrachiatus contortus Zone (NP10) and Discoaster binodosus Zone (NP11).

The Cretaceous/Paleogene $(\mathrm{K} / \mathrm{Pg})$ boundary is marked by the absence of nannoplankton NP1 Zone and the planktonic (P0 and P1 Zones). The K/Pg boundary is located at the top of CC26b. This boundary lies in the middle part of the Dakhla Formation. The Danian/Selandian boundary can be placed inthe uppermost part of Zone NP4 and nearly at the top of P3a Subzone in the upper part of the Dakhla Formation. The Selandian/Thanetian boundary can be drawn at NP6/ NP7/8 zonal boundary, and the upper part of P4 Subzone within the Esna Formation. The Paleocene/Eocene (P/E) 
boundary can be traced at the base of the E1Zone and at the base of the NP9b Subzone in the upper part of Esna shale

Key words: Gebel Duwi, Paleocene/Eocene, Foraminifera, Calcareous Nanofossils, Biostratigraphy.

\section{Introduction}

The Upper Cretaceous-Lower Eocene successions in Egypt have attracted several studies with special emphasis on the general geology, stratigraphy and paleontology (e.g., Said and Kenawy (1956), Youssef and Abdel Malik (1969), Abdel Malik et.al. (1978), Masters (1984), Faris et al. (1986), Hewaidy (1987), Cherif et al. (1989), Shahin (1988, 1992 and 2001), Ziko et al. (1993), Khalil (1986, 1993, 1998 and 2001), Kora et al. (1994 and 2001), Ismail and El Saadany (1995), Tantawy et al. (2000), Kora et al. (2002) and Samir (2002), EL-Nady (2005), Obaidalla (2005), Obaidalla, et al. (2008)and EL-Azabi and Farouk (2010).

A relatively thick Cretaceous-Eocene succession was measured and sampled from Gebel Duwi and Gebel Atshancentral Eastern Desert (Fig.1).The studied area is located to the west of Qusseir at Gebel Duwi

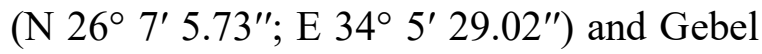
Atshan (N 26 $4^{\circ} 37.27^{\prime \prime} \mathrm{E} 34^{\circ} 9^{\prime} 24^{\prime \prime}$ ) (Fig. $1)$.

The main objectives of the present study are to: 1) recognize the different lithostratigraphic units in the studied area and to correlate them with different rock units in Egypt. 2) integrate the data obtained from planktonic foraminifera and calcareous nannofossils to subdivide the Late Maastrichtian-Early Eocene into several biostratigraphic units. 3) discuss somestage boundaries.

\section{Materials and methods}

The stratigraphic two sections were measured and sampled and a total of 353 rock samples were collected. For planktonic foraminiferal study, the samples have been washed and picked and the different species have been examined and identified using a

binocular microscope with maximum 40x magnification. The first and last appearances of a species were identified based on random representative splits with 300-400 individuals from the $>63 \mu \mathrm{m}$ size fraction. The remaining sample residue was investigated for rare species and any other vital observations.

For the calcareous nannofossil study, samples were processed by smear slide preparation from raw sediment samples (Perch-Nielsen, 1985).

\section{Lithostratigraphy}

The lithostratigraphic subdivisions of the studied succession in Gebel Duwi and Gebel Atshansections throughout the Late Cretaceous-Early Eocene interval are based mainly on field observations and lithologic characters. The Upper Cretaceous-Lower Eocene succession along the studied sections is differentiated into five lithostratigraphic units: Duwi, Dakhla, Tarawan, Esna and Thebes formations, (Fig. 2). A detailed lithostratigraphic description of the measured sections is summarized in (Figs. 3, 4). In the following a brief account on each of these rock units arranged from bottom to top:

\subsection{Duwi Formation}

Author and type section: The name Duwi Formation was introduced by Youssef (1957) to define this unit at Gebel Duwi, central Eastern Desert.

Stratigraphic boundaries and description: In the studied succession, the top most part of the Duwi Formation is represented by about $10 \mathrm{~m}$ thick of limestone, yellow, hard, dolomitic, highly fossiliferous (oyster band) in the lower part and marl, yellow to grey, fossiliferous with thin phosphatic bands in the upper part at Gebel El Duwi section. The 
Duwi Formation conformably underlies the Dakhla Formation (Figs 3, 5a, 5b).

Age: Various workers (El Tarabili, 1966; Abd El Razik, 1967; Issawi, 1972) assign a Maestrichtian age to the entire Duwi Formation

\subsection{Dakhla Formation}

Author and type section: The name Dakhla Formation was introduced by Said (1961, 1962) to define this unit along the scarp north of Mut, Dakhla Oasis, Western Desert, Egypt.

Stratigraphic boundaries and description: In the studied succession, Dakhla Formation attains a thickness of about $60 \mathrm{~m}$ in Duwi section. It is made up of calcareous shale, gypsiferous in the lower part. The middle part of the formation is about $5 \mathrm{~m}$ thick and is composed of hard argillaceous limestone and dolomite. The upper part of the formation is composed of calcareous shale, grey to greenish grey, sometimes reddish, gypsiferous with reddish yellow marl intercalations. This unit conformably underlies the Tarawan Formation and overlies the Duwi Formation (Figs, 5, 6).

Age: The recorded Planktonic foraminiferal (CF4, CF3, CF2, P1a, P1b, P2, P3a, P3b) and calcareous nannofossil (Cc25c, Cc26b) biozones are suggested that this formation is assignanble to Late Maastrichtian-Middle Paleocene.

\subsection{Tarawan Formation}

Author and type section: The name Tarawan Formation was introduced by Awad and Ghobrial (1965) to define this unit at Gebel Teir/Tarawan, Kharga Oasis, Western Desert.

Stratigraphic boundaries and description: It attains $15 \mathrm{~m}$ thick in the Gebel Duwi and its upper part $(5 \mathrm{~m})$ only is measured in Gebel Atshansections. The Tarawan Formation is made mainly up of creamy white chalk with reddish yellow marl intercalations and chert nodules (Fig. 3, 5a). The Tarawan Formation lies conformably between.shale units (Dakhla and Esna) with no remarkable hiatus in the studied sections (Fig. 5b).

Age: The recorded Planktonic foraminiferal (P4) and calcareous nannofossil (NP5) biozones are suggested that this formation is assignanble to Middle Paleocene.

\subsection{Esna Formation}

Author and type section: The term "Esna Shale" is firstly given by Beadnell (1905) to describe the laminated green and grey shale sequence in Gabal Owaina, opposite Esna, Nile Valley.

Stratigraphic boundaries and description: The Esna Formation is conformably underlies the Thebes Formation and overlies the Tarawan Chalk with sharp contact between them (Figs.3,4, 5c, 6b,c). It is measured in the two studied sections (G. Duwi and G. Atshan), and attains a thickness of about $60 \mathrm{~m}$ and $55 \mathrm{~m}$ respectively. The Esna Formation is composed mainly of calcareous shale, greenish grey, graded upwardly into marl and argillaceous limestone in the lower and upper parts. The middle part of Esna Shale is formed of shale, greenish grey, gypsiferous with reddish yellow to grey marl and siltstone and /or hard phosphatic limestone intercalations.

Age: The recorded Planktonic foraminiferal (P4, P5, E1) and calcareous nannofossil (NP5, NP6, NP7/8, NP9a, NP9b) biozones are suggested that this formation is assignanble to Late Paleocene - Early Eocene.

\subsection{Thebes Formation}

Author and type section: The name Thebes Formation was applied by Said (1960) to describe a thick sequence of limestone with chert interbeds at Gabal Gurnah, near Luxor. 
Stratigraphic boundaries and description: The Thebes Formation conformably overlies the Esna Formation in the two studied sections (Figs. 3,4,5c,6a,b,c). This unit is about $150 \mathrm{~m}$ thick and subdivided informally to lower, middle and upper members. The lower member is made up of argillaceous limestone in lower part and chalky in upper part with thin chert band and nodules. It is rich in marine macro- and micro-fauna especiallyTurritella and Nummulites. The middle one characterizes by limestone and chert bands intercalations. A disconformity surface is observed in the field within the middle part. Argillaceous limestones are the main components of the upper member of the Thebes Formation.

Age: The recorded Planktonic foraminiferal (E2, E3, E4) and calcareous nannofossil (NP10, NP11) biozones are suggested that this formation is assignanble to Early Eocene.

\section{Biostratigraphy}

The Cretaceous biostratigraphic zonation is used here and based on the (CF) zonal scheme of Li \& Keller (1998), where the Paleocene and Early Eocene biozones are based on the zonal scheme of Berggern \& Pearson (2005). Nannofossil biostratigraphic framework is applied according to the biozonation scheme of Sissingh (1977) and Prech-Nielsen (1981) for the Late Cretaceous. The Lower Paleogene Zonal Schemes of Martini (1971) and that of Romein (1979) have been followed.

Planktonic foraminifera and calcareous nannofossil assemblages are used to establish an integrated biostratigraphic zonation for the Paleocene-Lower Eocene successions in the area under consideration and to correlate the identified calcareous nannofossil biozones with time-equivalent zones worldwide. Planktonic foraminiferal and calcareous nannofossil biozones in the studiedsections are present in Figures $(3,4)$.

\subsection{Planktonic foraminiferal biostratigraphy}

According to the vertical distribution of planktonic foraminifera, the Upper Maastrichtian - LowerEocene succession can be subdivided into nine biozones. The identified planktonic foraminiferal zones in the studied section are illustrated (Figs. 3, 4). Some selected planktonic foraminiferal species are illustrated on Plates 1, 2. The following is the description of the established planktonic foraminiferal biozones arranged from older to younger:

\subsubsection{Late Maastrichtian biozones}

Abathomphalus mayaroensis Zone (CF1, CF2, CF3, CF4 zones of Li \& Keller, 1998)

Author: Bronnimann (1952) as the Globotruncana mayaroensis Zone

Age: Late Maastrichtian

Definition: This zone was defined by the total range of the nominated species. It characterizes the Late Maastrichtian of low latitude deep-sea successions as well as the tethyan palaeogeographic realm. $A$. mayaroensis disappears prior to the $\mathrm{K} / \mathrm{Pg}$ boundary in high latitude regions (Blow, 1979) and is rare or absent in shallow continental shelf sequences (Keller, 1988, 1989; Keller et al., 1995). In the present study, the A. mayaroensis species is not recorded in the studied samples. According to LI \& Keller, 1998 the A. mayaroensis Zone is subdivided into four subzones namely in stratigraphic order: Racemiguembelina fructicosa, Pseudoguembelina hariaensis, P. palpebra and Plummerita hantkeninoides subzones. Only three subzones were recorded in the present study. Plummerita hantkeninoides Zone represents the latest Maastrichtian biozone, according to many authors: Pardo et al. (1996) in Spain, Arz et al.(2001) in Mexico, Darvishzad et al. (2007) in Iran and Anan (2007, 2008a, b, 2011a, b and 2012) in 
Egypt. The topmost Maastrichtian Plummerita hantkeninoides Subzone (CF1Zone of Li \& Keller, 1998) is not recorded. Three subzones are described from base to top as follows:

\section{Racemiguembelina fructicosa Subzone (CF4)}

Author: Li \& Keller (1998)

Age: Late Maastrichtian

Definition: CF4 Subzone is defined to include the interval from the first appearance datum (FAD) of the Racemiguembelina fructicosaand the FAD of the Pseudoguembelina hariaensis.

Occurrence: Lowerpart of Dakhla Formation.

Characteristic planktonic foraminiferal assemblage: The dominant species in this subzone are Rugoglobigerina hexacamerata, $R$. rugosa, Pseudotextularia deformis, $P$. elegans, $P$. intermedia, Heterohelix dentanta, $H$. globulosa, $H$. moremani, $H$. navarroensis, $H$. reussi, Pseudoguembelina costulata and P. palpebra.

Pseudoguembelina hariaensis Subzone (CF3)

Author: Li \& Keller (1998)

Age: Late Maastrichtian.

Definition: CF3 Subzone was defined by Li $\&$ Keller (1998) as the partial range of the Pseudoguembelina hariaensisbetween its FAD and the last appearance datum (LAD) of Gansserina gansseri (Bolli). Gansserina gansseri (Bolli) is not recorded in the present samples. The upper boundary of the CF3 subzone is not clear.

Occurrence: Lower part ofDakhla Formation.

Characteristic planktonic foraminiferal assemblage: The dominant species in this subzone are Rugoglobigerina hexacamerata, $R$. macrocephala, $R$. rugosa, Pseudotextularia deformis, $P$. elegans, $P$. intermedia, Heterohelix dentanta, $H$. globulosa, H. moremani, H. navarroensis,
H. pulchra, H. reussi, H. striata, Pseudoguembelina costulata and $P$. palpebra.

Pseudoguembelina palpebra Subzone (CF2)

Author: Li \& Keller (1998)

Age: Late Maastrichtian

Definition: CF2 Pseudoguembelina palpebra Subzonewas defined by Li \& Keller (1998) as the partial range of the nominate taxon between the LAD of Gansserina gansseri to the FAD of Plummerita hantkeninoides. This subzone is indicated in the present study by the occurrence of Pseudoguembelina palpebra (Bronnimann).

Occurrence: Lower part ofDakhla Formation.

Characteristic planktonic foraminiferal assemblage: The dominant species in this subzone are Rugoglobigerina hexacamerata, $R$. macrocephala, $R$. robusta, $R$. rugosa, $R$. scotti, Archaeoglobigerina blowi, Pseudotextularia deformis, P. elegans, Heterohelix dentanta, $H$. glabrans, $H$. globulosa, H. moremani, H. navarroensis, H. pulchra, $H$. reussi, $H$. striata, Pseudoguembelina costulata, P. palpebra, Globigerinelloides aspera, G. subcarinata and Hedbergella holmdelensis.

\subsubsection{Paleocene-Early Eocene biozones}

\section{Parasubbotina pseudobulloides Partial range (Subzone $\mathrm{P} 1 \mathrm{a})$.}

Author: Bolli (1966) (renamed by Berggren and Pearson (2005) from Parvularugoglobigerina eugubinaSubbotina triloculinoides--Zone [P1a] of Berggren et al. 1995; emendation of Berggren and Miller, 1988).

Age: Early Paleocene (Early Danian).

Definition: Partial range of the nominate taxon between the $\mathrm{HO}$ of 
Parvularugoglobigerina eugubina and the LO of Subbotina triloculinoides.

Occurrence: The Parasubbotina pseudobulloides Zone is recorded from the middle part of the Dakhla Formation.

Characteristic planktonic foraminiferal assemblage: Besides the marker species, this zone is characterized by the presence of Globanomalina compressa, Chiloguembelina midwayensis, Globanomalina archeocompressa, G. planocompressa, Praemurica polycamera, $P$. pseudoinconstans, P. taurica, Eoglobigerina edita, E. eobulloides, E. praedita, E. simplicissima and Subbotina trivialis.

Remarks and correlation: The $P$. pseudobulloides zone represents the oldest identified Danian planktonic foraminiferal zone in the studied section. It is characterized by the disappearance of the Cretaceous planktonic foraminiferal species and by the incoming of the Paleocene forms. The $P$. Pseudobulloides Zone is conformably overlain by the Subbotina triloculinoides Zone.

This zone is equivalent to the lower part of the Globigerina triloculinoidesGloboconusa daubjergensis Zone of Berggren (1969) in Libya, The Parasubbotina pseudobulloides Zone is matched with the Morozovella pseudobulloides Zone of Faris (1985), Hewaidy (1987) in north east Sinai, Aref et al. (1988), Shahin (1992) in west central Sinai, Khalil (1993) in Araif El-Naga. It coincides with the Subbotina pseudobulloides Zone of Premoli-Silva \& Bolli (1973), the Morozovella pseudobulloides Zone of Toumarkine and Luterbacher (1985). P1a Subzone is also correlated with $P$. pseudobulloides Zone described by El-Nady and Shain (2001), Obaidalla (2005) in southwestern Sinai, ELNady (2005) in northern Sinai and Galal and Kamel (2007) in the Eastern Desert.
Subbotina triloculinoides Lowest occurrence (Subzone P1b).

Author: Berggren et al., 1995, renamed by Berggren and Pearson (2005) from Subbotina triloculinoides-lobanomalina Compressa/Praemurica inconstans Subzone [Plb], Berggren et al., 1995; emendation of Berggren and Miller, 1988).

Age: Early Paleocene (Early to MidDanian).

Definition: Biostratigraphic interval from the LO of the nominate taxon to the LOs of G. compressa and/or P. inconstans.

Occurrence: The Subbotina triloculinoidesZone is recorded from middle part of the Dakhla Formation.

Characteristic planktonic foraminiferal assemblage: In addition to the index species, the planktonic foraminifers include; Parasubbotina pseudobulloides, $P$. moskvini, Subbotina trivialis, Chiloguembelina midwayensis, C. morsi, Globanomalina planocompressa, Praemurica polycamera, P. pseudoinconstans, P. taurica, Globanomalina compressa, Praemurica inconstans, Morozovella praecursoria, Globoconusa daubjergensis, Eoglobigerina edita, E. eobulloides, E. pentagona and Woodringina hornerstownensis.

Remarks and correlation: The $S$. triloculinoides Subzone is unconformably overlain by the Praemurica uncinata Subzone P2. Subzone P1b is identical to the Subbotina triloculinoides-Globanomalina compressa/Praemurica inconstans Interval Subzone (Plb) of Berggren et al., (1995). It is also equivalent to theSubbotina triloculinoidesZone described by Obaidalla (2005) in southwestern Sinai and Galal and KAamel (2007) in the Eastern Desert.

Praemurica uncinata Lowestoccurrence (Zone P2).

Author: Bolli (1966), renamed by Berggren and Pearson (2005) from Praemurica uncinata-Morozovella angulata zone [P2] of 
Berggren et al., 1995; emendation of, but biostratigraphically equivalent to Morozovella uncinata-Igorina spiralis zone [P2] ofBerggren and Miller, 1988.

Age: Late Early Paleocene (Late Danian).

Definition: Biostratigraphic interval between the LO of Praemurica uncinata and the LO of Morozovella angulata.

Occurrence: The Praemurica uncinata Zone is recorded from the middle part of the Dakhla Formation.

Characteristic planktonic foraminiferal assemblage: The characteristic planktonic foraminifers in this zone include: Parasubbotina pseudobulloides, Subbotina triloculinoides, Praemurica trinidadensis, P.inconstans, Morozovella praecursoria, Globoconusa daubjergensis and Eoglobigerina sp.

Remarks and correlation: The current zone is equivalent to the Globorotalia uncinata Zone defined by Bolli (1957 \& 1959) in Trinidad, Bolli \& Cita (1960) in Italy, Bolli (1966) in his general zonation, Premoli-Silva \& Bolli (1973), Stainforth et al. (1975), Globorotalia (Acarinina) praecursoria Zone of Blow (1979), Morozovella uncinata-Igorina spiralis Zone (P2) of Berggren \& Miller (1988). It coincides with the $\mathbf{P 2}$ zone proposed by Toumarkine and Luterbacher (1985), the same zone of Berggren and Pearson (2005). Morozovella angulata Zone conformably overlies this zone.

In Egypt, Praemurica uncinata Zone P2 is equivalent to that defined by El-Naggar (1966) in the Nile Valley, Youssef \& Abdel Malik (1969) in southwestern Sinai, Beckman et al. (1969), Abdel Malik et al. (1978) in west central Sinai, Faris (1985) at Ain Amur (NW Kharga), Hewaidy (1987) at El-Ain and El-Falig (NE Siani), Shahin (1988) at Gabal Nazzazat (SW Sinai) and El-Deeb \& El-Gammal (1994) at southwestern Sinai, Shahin (1992) in west central Sinai and Khalil (1993) in Araif El-
Naga area. Parasubbotina pseudobulloides subzone is also correlated with $P$. pseudobulloides Zone described by El-Nady and Shain (2001), EL-Nady (2005) in northern Sinai, Galal and KAamel (2007) in the Eastern Desert and Khalil and Al Sawy (2014) in the wesren Desert.

Morozovella angulata Lowestoccurrence (Zone P3).

Author: Alimarina (1963), renamed by Berggren and Pearson (2005) from Morozovella angulata-Globanomalina pseudomenardii zone [P3] of Berggren et al. (1995); emendation of Berggren and Miller (1988).

Age: Early Late Paleocene (Selandian)

Definition: Biostratigraphic interval between the LO of Morozovella angulata and the LO of Globanomalina pseudomenardii.

Occurrence: The Morozovella angulata Zone is recorded from the upper part of the Dakhla Formation.

Characteristic planktonic foraminiferal assemblage: The planktic assemblage of this zone is predominated by: Globanomalina compressa, Luterbacheria chapmani, Morozovella angulata, $M$. acutispira, M. aequa, M. conicotruncata, $M$. acuta, M. simulatiltes, Igorina pusilla, I. albeari, Acarinina primitive, $A$. subsphaerica, Muricoglobigerina mckannai and Subbotina irregularis.

Remarks and correlation: Based on higher resolution studies of material from DSDP Site 384, Berggren et al. (2000) renamed the Morozovella angulataZone to accord with the convention that the nominate taxon should be present within the zone. This zone is biostratigraphically identical to the Morozovella angulata-Globanomalina pseudomenardii Interval Zone (Zone P3) of Berggren et al., (1995).Morozovella angulataZone P3 coincides with that of Premoli-Silva and Bolli (1973), Stainforth et al. (1975), Toumarkine and Luterbacher 
(1985), the lower Morozovella angulata (P3a) subzone of Berggren \& Miller (1988) and P3 Zone of Berggren and Pearson (2005).

In Egypt, this zone is equivalent to the Globorotalia angulata Zone described by Beckmann et al. (1969), Faris (1984) at the Red Sea Coast and Faris (1985) at Ain Amur section. It is also correlated with the Morozovella angulata Zone of Hewaidy (1987) at El Quseima section, El-Deeb \& ElGammal (1994) at southwestern Sinai, Shahin (1992) in west central Sinai, Khalil (1993) in Araif El-Naga area, Faris et al. (2000) in Sinai, EL-Nady (2005) in northern Sinai, Galal and Kamel (2007) in the Eastern Desertand Khalil and Al Sawy (2014) in the wesren Desert.Recently, Obaidalla et al. (2009) divided this interval into three zones: Morozovella angulata, Igorina albeari/Praemurica carinata and Igorina albeari Zones. This subdivision cannot be applied in this study because it needs more high-resolution sampling.

\section{Igorina pusilla Partial range (Subzone P3a).}

Author: Bolli 1957a, emended by Berggren eta al. (1995) and renamed by Berggren and Pearson (2005).

Age: early late Paleocene (Selandian).

Definition: Biostratigraphic interval defined by the partial range of Igorina pusilla between the LO of Morozovella angulata and the LO of Igorina albeari.

Occurrence: The Igorina pusilla Subzone is recorded from the upper part of the Dakhla Formation.

Remarks and correlation:This subzone is equivalent to P3a Subzone of Berggren et al. (1995); Berggren and Pearson (2005), Galal and Kamel (2007) in the Eastern Desert, Khalil and al Sawy (2014) and to Morozovella angulata Zone of Obaidalla (2006).
Igorina albeari Lowest occurrence (Subzone P3b).

Author: Bolli 1957a, emended by Berggren eta al. (1995) and renamed by Berggren and Pearson (2005).

Age: early late Paleocene (Selandian).

Definition: Biostratigraphic interval defined by the partial range of Igorina pusilla between the LO of Morozovella angulata and the LO of Igorina albeari.

Occurrence: The Igorina albeari Subzone is recorded from the upper part of the Dakhla Formation and the Tarawan Formation.

Remarks and correlation: This subzone is equivalent to P3b Subzone of Berggren et al. (1995); Berggren and Pearson (2005), Galal and Kamel (2007) in the Eastern Desert, Khalil and Al Sawy (2014), and to the the combined Igorina albeari and Igorina albeari/Praemuricacarinata Zones of Obaidalla (2006).

\section{Globanomalina pseudomenardii Taxon range (Zone $\mathbf{P 4}$ ).}

Author: Bolli (1957a) as Planorotalites pesudomenardii Zone.

Age: Late Paleocene (late SelandianThanetian).

Definition: This zone was originally introduced by Bolli(1957), and it is defined as the biostratigraphic interval characterized by the total range of the nominate taxon Globanomalina pseudomenardii.

Occurrence: The Globanomalina pseudomenardii Zone occurs within the topmostpart the Tarawan and the lower part of Esna Formation.

Characteristic planktonic foraminiferal assemblage:

The Globanomalinapseudomenardii Zone includes the following species in addition to the marker species; Igorina pusillapusilla, Morozovella occlusa and Pseudohastigerina wilcoxensis.

Correlation: This zone is equivalent to the Globorotalia pseudomenardii Zone defined 
by Bolli (1957 \& 1959) in Trinidad, Bolli \& Cita (1960) in Italy, Bolli (1966) in his general zonation, Berggren (1969), PremoliSilva \& Bolli (1973), Stainforth et al. (1975), Toumarkine \& Luterbacher (1985) and Berggren \& Miller (1988). It coincides with P3 Zone of Berggren and Pearson (2005). The current subzone corresponds to the P4a, P4b and P4c Subzones of Berggren et al. (1995) and Berggren and Pearson (2005).

In Egypt, the Globanomalina pseudomenardii Zone coincides with the Planorotalites pseudomenardii proposed by El-Naggar (1966) in the Nile Valley as a subzone in the Globorotalia velascoensis Zone, Abdel Malik et al. (1978) in west central Sinai, Faris (1984), Faris et al. (1986) at Abu Had, El Serai and Taramsa sections, Hewaidy (1987) in El-Qusaima area, Aref et al. (1988) along the Red Sea Coast, El-Deeb \& El-Gammal (1994) at southwestern Sinai, Faris et al. (2000) in north and southwest Sinai, Galal and Kamel (2007) in the Eastern Desert and Khalil and al Sawy (2014) in the western Desert.

\section{Morozovella velascoensis Partial range (Zone P5).}

Author: Bolli (1957).

Age: Late Paleocene (latest Thanetian).

Definition: This zone was originally defined by Bolli (1957a) from the Upper Paleocene rocks of Trinidad. It includes the biostratigraphic interval characterized by the partial range of the nominate taxon between the HO of Globanomalina pseudomenardii and the LO of. Acarinina sibaiyaensis.

Occurrence: This zone is recorded from the upper part of the Esna Shale.

Characteristic planktonic foraminiferal assemblage: This zone is characterized by the diversification of planktonic species including Morozovella aequa, $M$. conicotruncata, M. acuta, M. occlusa, Acarinina soldadoensis, A. mckannai, A. primitiva, A. nitida, Subbotina velascoensis and Subbotina linaperta.

Correlation: The Morozovella velascoensis Zone was recorded firstly from the Lizard Springs Formation of Trinidad by Bolli (1957, 1966). It coincides with that of Bolli and Cita (1960) in Italy, Postuma (1971) world wide, Premoli-Silva and Bolli (1973) in Italy, Stainforth et al. (1975) world wide and Toumarkine \& Luterbacher (1985) in their general zonation.

In Egypt, it is equivalent to that described by Abdel Malik et al. (1978) in west central Sinai, Hewaidy (1987) in El-Qusaima area, Aref et al. (1988) in Red Sea Coast, Shahin (1988) at Gebel Nezzazat, El-Deeb \& ElGammal (1994) at southwestern Sinai, Galal and Kamel (2007) in the Eastern Desert and Khalil and al Sawy (2014) in the western Desert.

Acarinina sibaiyaensis Lowest occurrence (Zone E1).

Author: Molina et al., 1999; emended by

Berggren and Pearson, 2005

Age: earliest Eocene (earliest Sparnacian).

Definition: Biostratigraphic interval between the LO of the nominate taxon Acarinina sibaiyaensis and the LO of Pseudohastigerina wilcoxensis.

Occurrence: This zone is recorded from the uppermostpart of the Esna Formation.

Characteristic planktic foraminiferal assemblage: The zone is marked by the presence of; Planorotaliteschapmani, Morozovellaaequa, $M$. caucasica, $M$. subbotinae, M. marginodentata, M. quetra and $M$. gracilis.

Remarks and correlation: The base of this zone coincides with the defined Global Stratotype Section and Point (GSSP) for the base of Eocene Series, in the Dababya section, south of Luxor, Nile Valley, where the Acarinina sibaiyaensis is so far the most common taxon among the three excursion taxa and occur in large number in some of 
the CIE interval (Berggren and Ouda, 2003a).

This zone may be equivalent to both the subzones P5b and one P5c of Molina et al. (1999).The Morozovella edgari Zone may be correlated with the Globorotalia aequa Zone of Luterbacher (1964). It corresponds to the lower part of the Globorotalia subbotinae Zone of Stainforth et al. (1975), the lower part of the subzone P6b of Berggren \& Miller (1988) andE1 zone of Berggren and Pearson (2005).

In Egypt, this Zone coincides with the Globorotalia wilcoxensis Zone of El-Naggar (1966), the Morozovella edgari Zone of Faris et al. (2000), to the same zone described by Nassif \& Omran (2001) in Wadi Watir area, Subzone P5b of Galal and Kamel (2007) in the Eastern Desert and E1 Zone Khalil and al Sawy (2014) in the western Desert.

\section{Pseudohastigerina wilcoxensis- Morozovella velascoensis Concurrent range (Zone E2).}

Author: (Berggren and Pearson, 2005)

Age: Early Eocene.

Definition: Biostratigraphic interval characterized by the concurrent biostratigraphic ranges of the nominate taxa between the LO of Pseudohastigerina wilcoxensis and the $\mathrm{HO}$ of Morozovella velascoensis.

Occurrence: This zone is recorded from the lower part of Thebes Formation.

Characteristic planktic foraminiferal assemblage: This zone is characterized by the presence of the following species; Planorotalites chapmani, Morozovella aequa, M. caucasica, M. subbotinae, $M$. marginodentata, $M$. quetra, $M$. formosa formosa, $M$. formosa gracilis, $M$. lensiformis, Acarinina soldadoensis, $A$. primitiva (Finlay), A. nitida and Pseudohastigerina wilcoxensis.
Remarks and correlation: The current zone is biostratigraphically identical to the upper part of Morozovella velascoensis (P5) Zone of Berggren et al. (1995) and to Pseudohastigerina wilcoxensis Subzone of Molina et al. (1999). It is also equivalent to Subzone P5c of Berggren and Ouda (2003b) and E2 Zone of Berggren and Pearson (2005) and Khalil and al Sawy (2014) in the western Desert.

\section{Morozovella marginodentata Partial range Zone (E3).}

Author: Berggren and Pearson (2005)

Age: Early Eocene

Definition: Biostratigraphic interval characterized by the partial range of the nominate taxon between the $\mathrm{HO}$ of Morozovella velascoensis and LO of Morozovella formosa.

Occurrence: This zone comprises the middle part of Thebes Formation.

Characteristic planktic foraminiferal assemblage: This zone is characterized by the presence of Morozovella aequa, $M$. edgari, M. gracilis, M. marginodentata, $M$. subbotinae, Acarinina coalingensis, $A$. angulosa, $A$. pseudotopilensis, $A$. wilcoxensis and $A$. soldadoensis.

Correlation: The current zone is identical to Zone E3 of Berggren and Pearson (2005) and Khalil and Al Sawy (2014). It is also closely equivalent to the Globorotalia rexZone of Bolli (1957b); Acarinina berggerni Zone (P7) of Blow (1979) and the Morozovella subbotinae Pseudohastigerina wilcoxensis Zone (P6b) of Berggren and Miller (1988).

\section{Morozovella Formosa Lowest occurrence (Zone E4).}

Author: Berggren and Pearson (2005)

Age: EarlyEocene

Definition: Biostratigraphic interval between the LO of the nominate taxon 
Morozovella formosaand the LO of Morozovella aragonensis.

Occurrence: This zone comprises the upper part of Thebes Formation.

Characteristic planktic foraminiferal assemblage: The nominate species coexists with a characteristic association including; Morozovella subbotinae, A. soldadoensis, $A$. primitiva, A. nitida, Globigerina linaperta and Pseudohastigerina wilcoxensis,

Correlation: The E4 Zone is equivalent to the Globorotalia Formosa Formosa of Premoli-Silva \& Bolli (1973), M. formosa formosa of Toumarkine and Luterbacher (1985) and E4 Zone of Berggren and Pearson (2005).

In Egypt, this zone is equivalent to the Globorotalia formosa formosa Zone ofBeckmann et al. (1969) and to the M. formosa formosa Zone described by Ayyad (1996) in Wadi Qena. In Sinai, it coincides with the upper part of G. rex Zone of Youssef \& Abdel Malik (1969) in TayibaFeiran area, to the M. formosa formosa Zone defined by Faris et al. (1986) in Gebel Qabeliat, by Faris et al. (2000) at Wadi Matulla and Feiran, by Nassif \&Omran (2001) in the Wadi Watir area and by Khalil and Mashaly (2004) in Sinai and Khalil and Al Sawy (2014) in the Western Desert.

\subsection{Calcareous nannofossil biostratigraphy}

Nannofossil biostratigraphic framework is applied according to the biozonation scheme of Sissingh (1977) and Prech-Nielsen (1981) for the Late Cretaceous. Meanwhile, the Lower Paleogene rocks comprise many zones from NP1 to NP11 according to the Zonal Scheme of Martini (1971). Furthermore, the subdivisions of the Paleocene biozones proposed by Romein (1979) have been followed For the Paleocene and Eocene, we adopt the biozonation proposed by Martini (1971) and emended by Aubry et al. (2000).
.A total of 82 nannofossil species were identified from the Upper Cretaceous-Early Eocene rocks of the studied sections. Some representative calcareous nannofossil species are illustrated in Plates $(3,4)$. Calcareous nannofossils are common to abundant in most studied samples and generally well preserved. The recognized biozones, subzones and the correlation between them are discussed below from base to top:

\subsubsection{Late Maastrichtian biozones Miculamurus Subzone (CC25c)}

Author: Romein (1979)

Age: Late Maastrichtian.

Definition: It is defined as the interval from the FO of Micula murus to the FO of $N$. frequens.

Occurrence: Lower part from Dakhla formation.

Characteristic nannofossil assemblage: Besides the marker species, this zone is dominated by Micula decussata, Watznaueria barnesae, Thoracosphaera operculata, Prediscosphaera cretacea, Eiffellithus gorkae, Arkhangelskiella cymbiformis, Eiffellithus turrisieffelii and Cyclagelosphaera reinhardtii. The most important calcareous nannofossil species that appear in this zone include; Lithraphidites quadratus, Manivitella pemmatoidea, Chiastozygus amphipons/litterarius, Ahmuellerella octoradiata and Prediscosphaera grandis.

Remarks and correlation: The present subzone is equivalent to the lower part of Lithraphidites quadratus Zone of Roth (1978) and Doeven (1983) and the upper part of Arkhangelskiella cymbiforms of Sissingh (1977), Lithraphidites quadratus Zone of Thierstein (1976) and Verbeek (1977), CC25b Subzone of Perch-Nielsen (1985a), CC25c Subzone of Khalil and Zahran (2014) in Sinai. 
Miculaprinsii Subzone (CC26b)

Author: Perch-Nielsen (1979)

Age: Late Maastrichtian.

Definition: The Micula prinsii Subzone is defined as the interval from the FO of Micula prinsii Perch-Nielsen to the increased frequency of Thoracosphaera operculata Bramlette \& Martini.

Occurrence: Lower part from Dakhla formation.

Characteristic nannofossil assemblage: Besides the marker species, this zone is dominated by Eiffellithus gorkae, Arkhangelskiella cymbiformis, Eiffellithus turrisieffeliiand Cyclagelosphaera reinhardtii. The most important calcareous nannofossil species that appear in this zone include; Lithraphidites quadratus, Manivitella pemmatoidea, Chiastozygus amphipons/litterarius, Ahmuellerella octoradiata and Prediscosphaera grandis.

Remarks and correlation: The upper limit cannot be determined with accuracy in the two studied sections due to a large hiatus observed at the base of the Paleocene.

\subsubsection{Paleocene-Early Eocene biozones Cruciplacolithus tenuis Zone (NP2)}

Author: Mohler and Hay in Hay et al. (1967), emend Martini (1970)

Age: Early Paleocene (Danian).

Definition: This is defined as the interval from the first occurrence $\mathrm{FO}$ of Cruciplacolithus tenuis to the FO of Chiasmolithus danicus.

Occurrence: Middle part from Dakhla formation.

Characteristic nannofossil assemblage: In addition to the marker species, this zone is characterized by the presence of Watznaueria baranesae, Eiffellithus gorkae, Eiffellithus turresreffeli, Cylindralithus gallica, Arkhangelskiella cympiformis, Ericsonia universa, Sphenolithus primus, Ericsonia robusta, Ericsonia subpertusaandThoracosphaera sexa.
Remarks and correlation: Cruciplacolithus tenuis Zone represents the earliest Paleocene zone in the studied sections.

\section{Ellipsolithus macellus Zone (NP4)}

Author: Martini (1970)

Age: latest Danian-early Selandian

Definition: The Ellipsolithus macellus Zone is defined as the interval from the FO of Ellipsolithus macellus to the FO of Fasciculithus tympaniformis.

Occurrence: Middle part of Dakhla formation.

Characteristic nannofossil assemblage: The calcareous nannofossil assemblage characteristic of this zone contains Chiasmolithus danicus, Cruciplacolithus primus. Cr. tenuous, Placozygus sigmoides and Ellipsolithus spp. are occurred rarely in this zone. The first representatives of Fasciculithus (F. billii, F. uliiand, F. janii); Sphenolithus (Sphenolithus primus) were also observed in this zone.

Remarks and correlation: In the study sections, Zone NP4 corresponds to the same zone described byFaris and Farouk (2012), Faris et al. (2012), Khalil and Zahran (2014) and Khalil and Al Sawy (2014). The present zone is also equivalent to CP3 Zone of Okada and Bukry (1980); Faris and Abu Shama (2007).

\section{Fasciculithus tympaniformis Zone (NP5)}

Authors: Mohler and Hay in Hay et al. (1967)

Age: Middle Paleocene (Selandian)

Definition: The Fasciculithus tympaniformis Zone is defined as theinterval from the FO of Fasciculithus tympaniformis to theFO of Heliolithus kleinpellii.

Occurrence: Upper part from Dakhla Formation, Tarawan Formation and the lowermost part of Esna Formation.

Characteristic nannofossil assemblage: Arkhangelskiella cympiformis, Ericsonia 
universa, Fasciculithus involutus, Sphenolithus primus, Fasciculithus ulii, Coccolithus peligicus, Ericsoniacava, Toweius eminens, Chiasmolithus danicus, Thoracosphaera sexa, Cruciplacolithustenuis, Heliolithus contabriae and Bombolithus elegans dominated this zone besides the marker species.

Remarks and correlation: Fasciculithus tympaniformis Zones equivalent to NP5 Zone of Martini (1971), the Fasciculithus tympaniformis zone of Romien (1979), and the CP4 Zone of Okada and Bukry (1980).Zone NP5 was previously recorded in many areas in Egypt: El Ain (Faris, 1988a), Um el Huetat (Faris, 1988b), El Shagab (Faris et al., 1999), west central Sinai (Abu Shama \& Faris, 2005), Faris and Abu Shama (2007), Faris and Salem (2007), Western Desert (Khalil and Al Sawy, 2014) and Sinai (Khalil and Zahran, 2014).

Heliolithus kleinpellii Zone (NP6)

Authors: Mohler and Hay in Hay et al. (1967)

Age: Middle Paleocene (latest Selandian)

Definition: The Heliolithus kleinpellii Zone is defined as the interval from the FO of Heliolithus kleinpellii to the FO of Discoaster mohleri.

Occurrence: Esna Formation.

Characteristic nannofossil assemblage: This zone dominated besides the marker species by the following species: Arkhangelskielle cympiformis, Ericsonia universa, Fasciculithus involutus, Sphenolithus primus, Fasciculithus ulii, Coccolithus pelagicus, Ericsoniacava, Toweius eminens and Chiasmolithus danicus.

Remarks and correlation: Heliolithus kleinpellii Zones equivalent to NP6 recorded by Abu Shama and Faris (2005), Faris and abu Shama (2007), Faris and Salem (2007) and Khalil and Al Sawy, 2014).

\section{Discoastermohleri Zone (NP7/ NP8)}

Authors: Hay (1964)

Age: Late Palaeocene (Thanetian)

Definition: Discoastermohleri Zones defined by the LO of Discoaster mohleri at the base and the LO of Discoaster multiradiatus at the top.

Characteristic nannofossil assemblage: This zone dominated besides the marker species by the following species: Arkhangelskielle cympiforms, Ericsonia, universa, Fasciculithus involutus, Sphenolithus primus, Fasciculithus ulii, Coccolithus pelagicus, Ericsoniacava, Toweius eminens, Chiasmolithus danicus, and Thoracosphaerasexa.

Remarks and correlation: This zone is equivalent to the combined NP7 and NP8 Zones of Martini (1971), the combined CP6 and CP7 Zones of Okada and Bukry (1980), and to the NP7/8 Zone of Faris and Abu Shama (2007), Faris and Salem (2007), Faris et al (2012) and Khalil and Al Sawy, 2014).

Occurrence: Upper part of Tarawan Formation.

\section{Discoaster multiradiatus Zone (NP9)}

Authors: Bramlette and Sullivan (1961): emended by Martini (1971)

Age: Late Thanetian-Early Eocene age.

Definition: includes the interval from LO of Discoaster multiradiatus to the LO of Tribrachiatus bramlettei.

Occurrence: Esna Formation.

Characteristic nannofossil assemblage: This zone dominated by Discoaster mahmoudii, D. binodosus, D. falcatus, D. lenticularis, $D$. araneus $D$. barbadiensis, $D$. diastypus and Zygrhablithus bijugatus.

Remarks and correlation: The present zone corresponds to NP9 Zone of Martini (1971), Romein (1979), Tantawy (2006), Faris and Salem (2007) and CP8 Zone of Okada and Bukry (1980). The NP9 Zone is well represented in several localities in Egypt (Faris et al., 1985, 1986; Faris, 1988a 
and Faris, 1991). It corresponds to NP9 Zone of Faris et al. (2012), Khalil and Al Sawy (2014) and Khalil and Zahran (2014). Aubry et al. (1999) subdivided the Discoaster multiradiatus Zone into two subzones (NP9a and NP9b) based on LO of Rhomboaster spp. and/or Discoaster araneus. This subdivision is applied here. The datum event of NP9a/NP9b subzonal boundary areadopted by the International Sub-commission on Paleogene Stratigraphy (ISPS) as one of the most important events that characterize the Paleocene/Eocene boundary interval.

\section{Tribrachiatus contortus Zone (NP10)}

Author: Hay (1964)

Age: Early Eocene (Ypresian)

Definition: The Tribrachiatus contortus Zone is defined as the interval from the FO of Tribrachiatus bramlettei to the LO of $T$. contortus.

Occurrence: Lower part of Thebes Formation.

Characteristic nannofossil assemblage: In the present study, other nannofossil species occur in Zone NP11, such as Zygrahablithus bijugatus, Discoaster barbadiensis, Discoaster binodosus, C. pelagicus, E. cava, and Chiasmolithus solitus.

Remarks and correlation: The Tribrachiatus contortus Zone is widely distributed in the Lower Eocene sediments in Egypt (e.g. Strougo \& Faris, 1993; Tantawy, 1998; Faris et al., 1999, Khalil and Al Sawy (2014) and Khalil and Zahran (2014). The NP10 zone corresponds to the Tribrachiatus contortus (NP10) Zone of Martini (1971), Romein (1979) and CP9a Subzone of Okada and Bukry (1980).

Aubry (1996) subdivided this zone based on the Tribrachiatus lineage into four subzones (NP10a, NP10b, NP10c and NP10d). None of these subdivisions can be differentiated in the current study. This may be attributed to large space of sampling and/or small hiatus.

\section{Discoaster binodosusZone (NP11)}

Author: Mohler and Hay in Hay et al. (1967)

Age: Early Eocene (Ypresian).

Definition: The Discoaster binodosus Zone is defined as the interval from the LO of $T$. contortus and the FO of Discoaster lodoensis.LO of Tribrachiatus contortus to FO of Discoaster lodoensis.

Occurrence: Middle to upper part of Thebes Formation.

Characteristic nannofossil assemblage: In the present study, other nannofossil species occur in Zone NP11, such as Zygrahablithus bijugatus, Discoaster barbadiensis, Discoaster binodosus,C. pelagicus,E. cava and Chiasmolithus solitus.

Remarks and correlation: Discoaster binodosus Zone (NP11)is equivalent to NP11 Zone recorded by Faris et al. in northern Oman and Khalil and Al Sawy (2014) in the western desert.

\subsection{Stage Boundaries}

The boundaries between stages are delineated based on the calcareous nannofossil and planktonic foraminiferal datum events as follow:

\section{1- The Cretaceous/Paleogene (K/Pg) boundary}

The Cretaceous/Tertiary boundary is marked by the absence of the latestMaastrichtian nannofossil Zone; CC26c, as well as the earliest Paleocene nannofossil biozones NP1. This boundary is also marked by the absence of the earliest Paleocene planktonic zones P0 and P1.At Gebel Duwi section the boundary is placed at the top of CC26b, in the lower part of the Dakhla Formation.

\section{2- Danian/Selandian boundary}

In the present study, in Gabal Gebel Duwi and Gebel Rewagen sections, the Danian/ Selandian boundary, lies at the uppermost part of Zone NP4 and nearly at the top of P3a subzone. It is located lithologically in the middle part of the Dakhla Formation 
4-Selandian/Thanetian boundary

nannofossil Zones NP6 and NP7/8 and the upper part

The Selandian/ Thanetian boundary corresponds tof the planktonic foraminifera P4 Subzone within the the lower part of the planktonic foraminifera P4 Zorfesna Formation. The Paleocene/Eocene boundary is (Berggren et al., 1995 and Berggren and Pearsonpproximately defined at the base of the planktonic 2005). For calcareous nannofossils, the base of tfforaminiferal Zone E1 and the base of the calcareous Thanetian Stage could be referred to the uppermosannofossil NP9b in the lower part of Esna shale. part of Zone NP6 or the lower most part of Zone NP6/

NP7 (Berggren et al., 1995).

Acknowledgements

In the present study, the Selandian/Thanetianhanks to Prof. Dr. M. Faris for assistance boundary is located within the lower part of the Esna the investigations of calcareous Formation and is tentatively drawn at the conformabheannofossils, critical reading and valiable contact between the calcareous nannofossil Zonssiggestions.

NP6 and NP7/8. This level is correlated to the upper part of the planktonic foraminifera P4 Subzone.

\section{References}

\section{5- Paleocene/Eocene boundary}

The Paleocene/Eocene boundary in the studied area placed at the base of the planktonic foraminifer Zone E1. It is correlative with the base of $t$ Calcareous nannofossil Subzone NP9b.

\section{Summery and conclusions}

The Upper Maastrichtian-Lower Eocene successions Abu Shama, A.M. and Faris, M., (2005): in Gebel Duwi and Gabel Atshan are differentiatedannofossil biostratigraphy of the into four rock units arranged from base to top Maastrichtian-lower Eocene rocks at Qalit Dakhla, Tarawan, Esna and Thebes Formations. Gendi section, Wadi Sudr, West Central Twelve planktonic foraminiferal biozones andinai, Egypt.-Egypt. J. Paleontol., 5: 161subzones were recognized, they are: CF4, CF3and 189.

CF2subzones (Late Maastrichtian); P1(P1a,P1b), PAlimarina, V. P. (1963): Some peculiarities P3(P3a,P3b),P4, P5 zones (Paleocene) and E1, E2n, the development of planktonic E3,E4 zones (Early Eocene). For calcareouforaminifera and zonation of the Lower nannofossils, ten biozones and subzones werealeogene of the northern Caucasus. identified, they are: CC25c, CC26b (latest Yoprosy Micropaleontol., 7: 158-195.

Maastrichtian); NP2, NP4, NP5, NP6, NP7/8, NP9a

(Paleocene), NP9b NP10, NP11(Early Eocene).

The Cretaceous/Paleogene $(\mathrm{K} / \mathrm{Pg})$ boundary (is 1988): Upper Cretaceous-Lower Tertiary marked by the absence of the earliest Paleoceplanktonic biostratigraphy along the nannofossil biozones NP1. It is also marked by thegyptian Red Sea region and its tectonic absence of the earlist Paleocene planktonic zones Poplication. Bull. of Faculty of Sci., Assiut and P1, and is tracedat the top of CC26b, in the lowerni.17(2F):171-201.

part of the Dakhla Formation. The Danian/Selandiantrz, J. A., I. Arenillas, A. R. Soria, L. boundary lies at the uppermost part of Zone NP4anAlegret, J. M. Gragales-Nishimura, C. L. nearly at the top of P3a Subzone. It is locatediesa, A. Melendez, E Molina\& M. C. lithologically in the middle part of the Dakhfosales (2001): Micropalentology and Formation. The Selandian/ Thanetian boundarydimentology across the corresponds to the contact between the calcareous retaceous/Tertiary boundary at La Ceiba (Mexico) : impact-generated sediment 
gravity flows. Journal of South American Earth Sciences, 14 : 505-519.

Anan, H. S. (2007): Paleontological and biostratigraphical remarks on some diagnostic Tethyan benthic foraminifera.2nd International Conference on the Geology of the Tethys, Cairo University, 2007: 303-308.

Anan, H. S. (2008a): Latest Maastrichtian Plummerita haggagae and Paleocene Pseudoclavulina hewaidyi, two newforaminiferal species from Egypt.Egyptian Journal of Paleontology, 8: 245-254.

Anan, H. S. (2008b): MaastrichtianPaleogene LeRoy's benthic foraminiferal species from Egypt and TethyanAtlanticregions.Revue de paléobiologie, 27 (2): $357-376$

Anan, H. S. (2011a): Maastrichtian small benthic foraminifera from Middle East and their distribution in the Tethys.Revue de Paléobiologie, 30 (1): 13-30.

Anan, H. S. (2011b): Additional to the Maastrichtian foraminifera of the Middle East.Revue de Paléobiologie, 30 (1):295311.

Anan, H. S. (2012): Paleontology, paleoecology, paleobathymetry, paleogeography and stratigraphic significance of the latest Maastrichtian genus Plummerita in Duwi section, Egypt and Tethys. Revue de Paléobiologie, Genève (décembre 2012) 31 (2): 589-600

Aubry, M-P., (1996): Towards an upper Paleocene-lower Eocene high resolution stratigraphy based on calcareous nannofossil stratigraphy. Israel Jour. of Earth Sciences, 44: 239-253.

Aubry, M.P., Berggren, W.A., Cramer, B., Dupuis, C., Kent, D.V., Ouda, Kh., Schmitz, B. and Steurbaut, E., (1999): Paleocene/
Eocene boundaries sections in Egypt. In: Late Paleocene-Early Eocene events from Northern Africa to the Middle East. Intern.Symposium in connection with 1 st Intern. Conf. on the geology of Africa, Nov. 23-25, 1999, Assiut, Egypt: 1-11.

Awad, G.H. and Ghobrial, M.G. (1965): Zonal stratigraphy of the Kharga Oasis.Ministry of Industry, General Egyptian Organisation for Geological Research and Mining, Geol.Surv. Egypt, Cairo, Paper 34, 77 pp.

Ayyad, S. N. (1996): Planktonic foraminiferal biostratigraphy of the Upper Cretaceous

-Lower Tertiary succession in the northern Wadi Qena, Nile Valley, Egypt.N. Jb. Geol. Palent.Mh., 10:581-604.

Beadnell, H.J.L. (1905): The relation of the Eocene and Cretaceous systems in the EsnaAswan streach of the Nile Valley. -Quart. J. Geol. Soc. London, 61:667-676.

Beckmann, J. P., El Heiny, I, Kerdany, M. T., Said, R. and Viotti, L. (1969): Standard planktonic zones in Egypt.-Proc. 1stIntern. Conf. Plankt. Fossil.(Geneva, 1967),1: 92103.

Berggren, W. A., Kent, D. V., Swisher, C. C., Aubry, M. P. (1995): A revised Cenozoic geochronology and chronostratigraphy. In: Berggren,W.A., Kent, D.V., Aubry, M.P., and Hardenbol, J. (eds.), Geochronology, Time Scales and stratigraphic correlation. SEPM special publication No. 54: 129-212.

Berggren, W. A., Aubry, M. P., Fossen, M., Kent, D. V., Norris, R. D. and Quillévéré, F. (2000): Integrated Paleocene calcareous plankton magnetobiochronology and stable isotope stratigraphy: DSDP Site 384 (NW Atlantic Ocean). Paleogeogr., Paleoclim.,Paleoecol., 159: 1-51. 
Berggren, W.A., (1969): Rates of evolution in some Cenozoic planktonic foraminifera. Micropaleont., 15: 351-365.

Berggren, W.A. and Miller, K.G. (1988): Paleogene tropical planktonic foraminiferal biostratigraphy and magnetobiochronology. Micropaleontol., 34: 362-380.

Berggren, W. A. \& Van Couvering, J. A. (1974): Neogene biostratigraphy, Geochronology andPaleoclimataology of the last 15 million years in marine and continental sequences.Palaeogeog., Palaeoclimatol., Palaeoecol., 16: 1- 216.

Berggren, W.A. and Ouda, Kh., (2003a): Upper Paleocene-lower Eocene planktonic foraminiferal biostratigraphy of the Dababiya section, Upper Nile Valley (Egypt).Micropaleontol., supplement. 1(49): 61-92.

Berggren, W.A. and Ouda, Kh., (2003b): Upper Paleocene-Lower Eocene planktonic foraminiferal biostratigraphy of the Qreiya (Abu Had) section, Upper Nile Valley (Egypt).Micropaleontol., Spec. Publ., 49: 105-122.

Berggren, W.A. and Pearson, P.N., (2005): A revised tropical to subtropical Paleogene planktonic foraminiferal zonation. Jour. Foram. Res., 35: 279-298.

Berggren, W.A., Kent, D.V., Swisher, C.C. and Aubry, M.P., (1995): A revised Cenozoic geochronology and chronostratigraphy. In: Berggren, W.A., Kent, D.V., Aubry, M.-P., and Hardenbol, J. (eds.), Geochronology, Time Scales and stratigraphic correlation. SEPM spec. publ., 54: 129-212.

Bernaola, G., (2007): New high resolution calcareous nannofossil analysis across the Danian/Selandian transition at the Zumaia section: comparison with south Tethys and Danish sections. In: International Workshop of the Paleocene Working Group (Zumaia, Basque Country). Abstract, 10-14.
Bernaola, G., Baceta, J.I., Orue-Etxebarria, X., Alegret, L., Martin-Rubio, M. and Dinarés-Turell, J., (2006): Calcareous nannofossil and foraminifera profiles across the Mid Paleocene biotic event at the classical Zumaia Section. In: 6th Intern. Conf. on the Climate and Biota of the Early Paleogene. Abstract, p. 19.

Bernaola, G., Martin-Rubio, M., and Baceta, J.J., (2009): New high resolution calcareous nannofossil analysis across the Danian/Selandian transition at the Zumaya section: Comparison with South Tethys and Danish sections. Geol. Acta, 7(1-2):79-92.

Blow, W.H. (1979): The Cenozoic Globigerinidae: A study of the morphology, axonomy, evolutionary relationships and the stratigraphical distribution of some Globigerinida mainly (Globigerinacea), E.J.Brill, Leiden, 3:1-1413.

Bolle, M. P., Pardo, A., Adatte, T., Von Salis, K. \& Burns, S. (2000): Climatic evolution on thesoutheastern margin of the Tethys (Negev, Israel) from the Paleocene to the Early Eocene:Focus on the late Paleocene thermal maximum. J. of Geo. Soc., 157: (5).

Bolle, M.P., Tantawy, A., Pardo, A., Adatte, T., Burns, S. and Kassab, A., (2000): Climate and environmental changes documented in the upper Paleocene to lower Eocene of Egypt. Ecl. Geol. Helv., 93: 3351.

Bolli, H.M., (1957a): Planktonic foraminifera from the Oligocene-Miocene Cipero and Lengua formations of Trinidad, BWI Bull. US Nat. Mus., 215: 97-123.

Bolli, H.M., (1957b): The genera Globigerina and Globorotalia in the Paleocene-Lower Eocene Lizard Springs formation of Trinidad. B.W.I.: United States Nat. Mus., Bull., 215:51-81.

Bolli, H. M., (1959): Planktonic foraminifera as index fossils in Trinidad, West Indies and their value for world-wide 
stratigraphic correlation. Ecl. Geol. Helv, Basel., 52, 637.

Bolli, H. M. and Cita, M. B., (1960): Upper Cretaceous and Lower Tertiary planktonic foraminifera from the Paderno d' Addo section, Northern Italy.21 st. Inter. Geol. Cong. 5: 150-160.

Bolli, H.M., (1966): Zonation of Cretaceous to Pliocene marine sediments based on planktonic foraminifera. Association Venezolanta de Geologia. Mineriay Petroleo, Bulletin Informativo, Zurich, 9(1): $3-32$.

Bown, P.R. and Young, J.R., (1998): Techniques. In: Bown, P. R. (ed), Calcareous Nannofossil Biostratigraphy. British Micropaleontol. Soc. Publ. Ser., p: 16-28.

Bramlette M.N. and Sullivan, F.R., (1961): Coccolithophorids and related Nannoplankton of the Early Tertiary in California.Micropaleontol., 7(2): 129-188.

Bronnimann, P. (1952): Trinidad Paleocene and Lower Eocene Globigerinidae. Bulletin of American Paleontology, 34 (143) : 1-34.

Caron, M., (1985): Cretaceous planktonic foraminifera. In: Plankton Stratigraphy (eds Bolli, H.M., Saunders, J.B. and PerchNielson, K.), Cambridge Uni. Press, 17-87.

Darvishzad, B.; Ghasemi-Nejad, E.; Ghourchaei, S. \& Keller, G. (2007): Planktonic foraminiferal biostratigraphy and faunalturnover across the $\mathrm{K} / \mathrm{Pg}$ boundary in southwestern Iran.Journalof Sciences, Islamic Republic of Iran, 18:139149.Doeven, P.H., 1983. Cretaceous nannofossil stratigraphy and paleoecology of the Canadian Atlantic Margin.- Bull. Geol. Surv. Can., 356: 1-70.

Dupuis, Ch., Aubry, M.P., Steurbaut, E., Berggren, W.A., Ouda, Kh., Magioncalda, R., Cramer, B., Kent, D.V., Speijer, R.P. and Heilmann-Clausen, C., (2003): The Dababiya Quarry Section: Lithostratigraphy, clay mineralogy, geochemistry and paleontology. Micropaleontol., Spec. Publ., 49: 41-59.

Dupuis, Ch., Aubry, M. P., Steurbaut, E., Berggren, W.A., Ouda, Kh.,Magioncalda, R., Cramer, B., Kent, D.V., Speijer, R.P. and Heilmann-Clausen, C. (2003): The Dababiya Quarry Section: Lithostratigraphy, clay mineralogy, geochemistry and paleontology. Micropal., Spec. Publ., 49: 41-59.

EL-Azabi, M.H and Farouk, S., (2010): High-resolution sequence stratigraphy of the Maastrichtian-Ypresian succession along the eastern scarp face of Kharga Oasis, southern Western Desert, Egypt, Sedimentol., 1-35. El-Bassiouni, A., Ayyad, S.N., Shahin A.M. and Shahin S.M., (2003): Planktonic foraminiferal bio-and- chronostratigraphy of the upper Maastrichtian- middle Eocene succession in northeastern Sinai, Egyptian Jour. of Paleontol., 3: 109-140.

El-Deeb, W. Z. M. and El-Gammal, R. M. H., (1994): Contributions to the biostratigraphy of Sudr and Esna Formations in southwestern Sinai area, Egypt. J. Geol., 3: 65-84.

El-Nady, H. (2005): The impact of Paleocene/Eocene $(\mathrm{P} / \mathrm{E})$ boundary events in northern Sinai, Egypt: Planktonic foraminiferal biostratigraphy and faunal turnovers. Revue de Paléobiologie, Genève, 24 (1) : 1-16

El Nady, H. and Shahin, A. (2001): Planktonic foraminiferal biostratigraphy and paleobathymetry of the Late Cretaceous Early Tertiary succession at northeast Sinai, Egyptian Jour.of Paleontol. , 193-227.

El-Naggar, Z. R. (1966): Stratigraphy and planktonic foraminifera of the Upper Cretaceous-Lower Tertiary succession in the Esna-Idfu region, Nile Valley, Egypt. Bull

.of the British Museum (Natural History), Geology 2:1-291. 
Faris, M. (1982): Micropaléontologie et Biostratigraphie du Crétacé supérieur et de $1^{\prime}$ Eocène inferieur de $1^{'}$ Egypte central (Region du Duvi, Vallée du Nill,Oasis de Kharga et de Dakhla). Thisde Doctorat D'Etat presenteé à 1'Uniersite Pierre et Marie Curie, Paris.1-538.

Faris, M., (1988a): Late Cretaceous/Early Tertiary calcareous nannofossils from El Qusaima area, NE Sinai, Egypt.-Bull. Fac. Sci. Qena, Assiut Uni., Egypt, 2 (1): 263275.

Faris, M., (1988b): Remarks on Late Paleocene/Early Eocene calcareous nannofossils from Gebel Um El-Huetat, Safaga, Egypt.-Bull. Fac. Sci. Qena, Assiut Uni., Egypt, 2 (1): 277-297.

Faris, M., (1991): Remarks on Late Paleocene-Early calcareous nannofossils from Gebel Gurnah section, Luxor, Nile Valley, Egypt.Delta Jour. Sci., 15 (2: 182211.

Faris, M., (1993): Paleoclimatology of the early Paleogene in Egypt by Calcareous nannofosils. Bull. Fac. of Sci., Assiut Uni., 2: 75-87.

Faris, M. and Abu Shama, A.M., (2007): Nannofossil biostratigraphy of the Paleocene-lower Eocene succession in the Themed area, east central Sinai, Egypt.Micropaleontol., 53(1-2): 127-144.

Faris, M. and Salem, R.F., (2007): Paleocene-early Eocene calcareous nannofossil biostratigraphy in west central Sinai, Egypt. Proceeding of the 8th Conf. Geology of Sinai for Deve., Ismailia, 1-14.

Faris, M. and Zahran, E., (2002): Calcareous nannofossil biostratigraphy of the Late Paleocene/ Early Eocene of El-Bruk area, North central Sinai, Egypt. Egypt. Jour. Paleontol., 2: 359-369.

Faris, M., Allam, A. and Marzouk, A.M., (1985): Biostratigraphy of the Late Cretaceous -Early Tertiary rocks in the Nile
Valley (Qena region), Egypt. Ann. Geol. Surv. Egypt, 15: 278-300: Cairo.

Faris, M., Abd El-Hameed, A.T. and Marzouk, A.M., (1986): The Cretaceous/Tertiary boundary in Taramsa section, West of Qena, Nile Valley, Egypt.Newsl. Stratigr., Berlin, Stuttgart, 16 (2): 85-97.

Faris, M., Ayyad, S.N., El-Nahass, H.A. and Al Wosabi, Kh., A. A., (2005): Early Paleogene stages and their boundaries, Sinai, Egypt.4th Intern. Conf. on the Geol. of Africa, Assiut Uni. Egypt, 2:753-768.

Faris, M., Abd El Hameed, A.T. and Shaaban, M., (1999): Calcareous nannofossil events at the Cretaceous/ Paleocene boundary in Central Egypt.1st Intern.Conf.on the geology of Africa, Nov. 23-25, 1999, Assiut, Egypt, 21-42.

Farouk, S. and Faris, M., (2012): Late Cretaceous calcareous nannofossil and planktonic foraminiferal bioevents of the shallow-marine carbonate platform in the Mitla Pass, west central Sinai, and Egypt. Cret. Res., 33: 50 - 65.

Galal, G. and Kamel, S., (2007): Early Paleogene Planktonic foraminiferal biostratigraphiy at the Monastery of Saint Paul, Southern Galala, Eastern Desert, Egypt. Rev. de Paleobiol., Geneve (decembre), 26(2): 391-402.

Gorostidi, A. and Lamolda, M.A., (1995): La nannoflora calcárea y el tránsito KT de la sectión de Bidart (south west de Francia). Rev. Español. de paleontol. (Homenaje al Dr. Guillermo Colom), 153-168.

Guasti, E., Speijer, R.P., Brinkhuis, H., Smit, J. and Steurbaut, E., (2006): Paleoenvironmental change at the DanianSelandian transition in Tunisia: Foraminifera, organic-walled dinoflagellate cyst and calcareous nannofossil records. Marine Micropaleontol. , 59: 210-229. Hay, W.W., (1964): The use of the electron microscope in the study of fossils.- Annual Rep. Smithsonian Inst., 409-415. 
Hay, W.W. and Mohler, H. P., (1967): Calcareous Nannoplankton from Early Tertiary Rocks at Pont Labau, France, and Paleocene-Early Eocene correlations.Jour. of Paleontol. , 41(6): 1505-1541.

Hewaidy, A. A., (1987): Biostratigraphy and paleobathymetry of the Esna Shale in ElQusaima area, North Sinai, Egypt. M.E.R.C., Ain Shams Univ. Earth Sci. Ser., 1: 180-206.

Hillebrandt, A.Von, (1965): Foraminiferen Stratigraphie im Altterti von Zumaya (Proinz Guipozcoa, NW-Spanien) und ein Vergleich mit anderen Tethys- Gpieten: Bayerische Akademie der Wissenschaften, Mathematisch- Naturwissenchaftliche Klasse, Aphandlungen, Neue Folge, 123: 162.

Ismail, A. A. and El-Saadany, A., (1995): Some Cretaceous foraminifera from northern Sinai, Egypt. M.E.R.C. Ain Shams Univ., Earth Sci. Ser. 9: 173-203.

Keller, G., L. LI \& N. Macleod (1995): The Cretaceous/Tertiary boundary stratotype section at El Kef, Tunisia: How Catastrophic was the mass extinction ?Palaeogeography,

Palaeoclimatology, Palaeoecology, 119 : 221-254.

Keller, G., (1988): Extinction, survivorship and evolution of plankticforaminifers across the Cretaceous/Tertiary boundary at El Kef,Tunisia: Marine Micropaleontology, v. 13, p. 239-263.

Keller, G. (1989): Extended the Cretaceous/Tertiary boundary extinction and delyed population changes in the planktonic foraminifera faunas from Brazos River, Texas. Paleoceanography, 4: 287-332.

Khalil, H., (1986): Geology of the area between Wadi Feiran and El-Tor, Southwest Sinai, Egypt. M. Sc. Thesis, Fac. Sci, Tanta Univ. (Unpubl.): 130 p.

Khalil, H., (1993): Stratigraphical and structural studies on Gebel Arif El-Naqa area, Sinai, Egypt. Ph.D. Thesis, Fac. Sci., Tanta Univ. (Unpubl.): 178 p.
Khalil, H., (1998): Late Cretaceous benthonic foraminiferal biostratigraphy, Sinai, Egypt. with special consideration to the genus Bolivinoides. N. Jb. Geol. Palaent. Mh. 7: 415-431.

Khalil, H., (2001): Paleocene/Eocene benthonic foraminiferal biostratigraphy, events and paleoecology in the Sinai, Egypt.N. Jb. Geol. Palaent. Abh. 220 (3): 313-334.

Khalil,s. and Meclay, k. (2002): Extensional fault-related folding, northwestern red sea, Egypt. Gournal of Structure Geology, 24:743-762.

Khalil, H. and Mashaly, S. (2004): Stratigraphy and stage boundaries of the Upper Cretaceous-Lower Paleogene succession in Gabal Musaba Salama area, southern Sinai, Egypt. Egypt. Jour. Paleontol.. 4, 1-38.

Khalil, H. Al Sawy, S. (2014): Integrated biostratigraphy, stage boundaries and Paleoclimatology of the Upper CretaceousLower Eocene successions in Kharga and Dakhala Oases, Western Desert, Egypt . J. African, Earth Science, 96, 220-242.

Khalil, H. and Zaharan, E. (2014): Calcareous Nannofossil Biostratigraphy and Stage Boundaries of the Santonian-Eocene Successions in Wadi El Mizeira Northeastern Sinai, Egypt. International Journal of Geosciences, 5.

Kora, M., Hamama, H. and Sallam, H., (2002): Senonian macrofauna from West Central Sinai: Biostratigraphy and paleobiogeography. Egypt. Jour. Paleontol., 2: $235-258$.

Knox, R.W.O.B. (1994): The age and regional context of the Thantian stratotype sections of south east England.-GFF 116: 55-56. 
Le Roy, L.W., (1953): Biostratigraphy of the Maqfi section, Egypt. Geol. Soc. Amer. Mem., 54, 73 p.

Li, L. and Keller, G., (1998): Maastrichtian diversification of planktonic foraminifera at El-Kef and Elles, Tunisia.- Ecl. Geol. Helv., 91: 75-102.

Li, L. and Keller, G., (1998a): Maastrichtian climate, productivity and faunal turnovers in planktonic foraminifera in South Atlantic DSDP sites 525A and 21. Marine Micropaleontol., 33: 55-86.

Luterbacher, H.-P.and Premoli-Silva, I., (1964): Biostratigrafiadel limite Cretaceo-Terziario nell Appennino Centrale.Revista Italiana di Paleontologia e Stratigrafia, 70: 67-128.

Martini, E. (1970): Standard Paleogene calcareous nannoplankton zonation.-Nature, 226:560-561.

Martini, E., (1971): Standard Tertiary and Quaternary calcareous nannoplankton zonation. In: Farinacci, A. (Ed.): proceeding II Plankt. conf., Roma, 1970, 2: 739-785.

Masters, B.A., (1984): Comparison of planktonic foraminifera at the Cretaceous Tertiary boundary from the El Haria Shale (Tunisia) and Esna Shale (Egypt). 7Th E.C.P.C. Explor. Semin. (Cairo): 1-21. Hay, W.W., Mohler, H.P., Roth, P.H., Schmidt, R.R and Boudreaux, J.E. (1967): Calcareous nannoplankton zonationof the Cenozoic of the Coast and CaribbeanAntillean area and transoceaniccorrelation.Trans. Gulf Coast. Association Geology Society, 17, 28-80.

Nassif, M. and Omran, M., (2001): Eocene planktonic foraminiferal biozonation of ElSheikh Atia section in wadi Watir area, southeastern Sinai, Egypt. Proceedings of the $6^{\text {th }}$ Conf. Geology of Sinai for development, Ismaillia, 231-238.

Molina, E., Arenillas, I. and Pardo, A., (1999): High resolution planktic foraminiferal biostratigraphy and correlation across the Paleocene/Eocene boundary in the Tethys. Bull. Soc. Geol. Fr., 170: 521530 .

Monechi, S., Angori, E. and Speijer, R., (2000): Upper Paleocene biostratigraphy in the Mediterranean region: Zonal marker, diachronism, and preservational problems. In: Schmitz, B., Sundquist, B. and Andreasson, F. (Eds.): Early Paleogene warm climates and biosphere dynamics.GFF, 122: 108-110.

Obaidalla, N.A., (2005): Complete Cretaceous/Paleogene (K/P) boundary section at Wadi Nukhul, southwestern Sinai, Egypt: inference from planktic foraminiferal biostratigraphy. Rev. de Paléobiol., Gen. (juin 2005) 24 (1): 201-224.

Obaidalla, N.A., (2006): Foraminiferal events across the Paleocene/Eocene $(\mathrm{P} / \mathrm{E}$ transition) at Wadi Tarfa, north Eastern Desert, Egypt. Bull. Fac. Sci., Assiut Uni. 35 (2): 1-37.

Obaidalla, N.A., Hewaidy, A.A., Hosny, A.M. and Mahfouz, K.H., (2008): The Paleocene/Eocene $(\mathrm{P} / \mathrm{E})$ transition at Kharga Oasis, Western Desert, Egypt: litho-, biostratigraphy and paleoenvironment. 8th Ann. Meet. Paleontol. Soc., Cairo, Abstract, pp. 7-8.

Obaidalla, N. A., El-Dawy, M. H. and Kasab, A. S., (2009): Biostratigraphy and paleoenvironment of the Danian/Selandian $(\mathrm{D} / \mathrm{S})$ transition in the SouthernTethys:Acase study from north EasternDesert, Egypt. Journal of African Earth Sciences, 53,1-15.

Okada, H. and Bukry, D., (1980): Supplementary modification and introduction of code numbers to the lowlatitude Coccolith Biostratigraphic Zonation 
(Bukry, 1973, 1975) - Marine Micropaleontol. , 5: 321-325.

Olsson, R. K., Berggren, W.A., Hemleben, C. and Huber, B.T. (1999): Atlas of Paleocene planktonic foraminifera. Smithsonian Contributions to Paleobiology, 85: 1-252.

Ortiz, S., Arenillas, I., Molina, E. and Peryt, D., (2006): The Danian/Selandian transition at the Zumaya Section, Northern Spain: Inferences from foraminifera. In: 6th Intern. Conf.on the Climate and Biota of the Early Paleogene. Abstract, p. 93.

Orue-Etxebarria X., Apellaniz, E. and Caballero, F., (2007): Discrepancies in planktic foraminiferal biostratigraphy across the Danian/Selandian transition at Zumaia: no poor preservation, but taxonomic different concepts. In: International Workshop of the Paleocene Working Group (Zumaia, Basque Country). Abstract, 25-27. Ouda, Kh.,Senosy, M.M. and Abdel Sabour, A., (2004): The Dababiya Quarry Beds and their significance as a marker litho- and biostratigraphic unit at the base of Eocene in the Kharga Oasis, Western Desert, Egypt. 5th Int. Conf., Climate Biota Early Paleogene (CBEP-V), Luxor, Egypt, Abstract, p. B-23.

Pardo, A., N. Ortiz and G. Keller (1996): Latest Maastrichtian and CretaceousTertiary boundary foraminiferal turnover and environmental changes at Agost, Spain.In: Macleod, N. \& G. Keller (Eds). Cretaceous-Tertiary mass extinction: biotic and environmental changes. W.W. Norton \& Company, New York-London, 139-171.

Pardo, A., Keller, G. and Oberhansli, H., (1999): Paleoecology and paleooceanographic evolution of the Tethyan realm during the Paleocene-Eocene transition. Jour. Foram. Res., 29: 37-57. Postuma, J. A. (1971): Manual of planktonic foraminifera. Elsevier Publishing Co., Amsterdam, 420 p.
Perch-Nielsen, K., (1981): New Maastrichtian and Paleocene calcareous nannofossils from Africa, Denmark, the USA and the Atlantic, and some Paleocene lineages.Ecl. Geol. Helv., 74: 831-863.

Perch-Nielsen, K., (1985): Cenozoic calcareous nannofossils. In: Bolli, H.M., Saunders, J.B. and Perch-Nielsen, K. (eds): Plankton Stratigraphy.-Cambridge Uni. Press: 427-554.

Premoli- Silva, I. \& H. M. Bolli (1973): Late Cretaceous to Eocene planktonic foraminifera and stratigraphy of Leg 15 sites in the Caribbean Sea. In : EDGAR, N. T., J. B. SAUNDERS

Rodrígueaz, O. and Aubry, M.P., (2006): Lower to Middle (Danian-Selandian) Paleocene calcareous nannofossil stratigraphy of the Qreiya Section (Egypt). In: 6th Intern. Conf. on the Climate and Biota of the Early Paleogene. Abstract, p. 111.

Romein, A.J.T., (1979): Lineages in Early Paleogene calcareous nannoplankton.Utrecht Micropaleontol. Bull. , 22: 1-231.

Roth, P. H. (1978): Cretaceous nannoplankton biostratigraphy and oceanography of the NorthwesternAtlantic Ocean. Init. Rep. DSDP, 44: 731-759.

Said, R., (1960): Planktonic foraminifera from the Thebes Formation, Luxor, Egypt. Micropaleontol. , 6: 277-286.

Said, R., (1962): The Geology of Egypt, (Elsevier, Amsterdam), 377 pp.

Said, R. and Kenawy, A., (1956): Upper Cretaceous and Lower Tertiary foraminifera from northern Sinai, Egypt. Micropaleont., 2: 105-73.

Samir, A. (2002): Biostratigraphy and paleoenvironmental changes in the Upper Cretaceous-Early Paleogene deposits of Gabal Samra section, southwestern Sinai, Egypt. Egypt J. Paleontol., 2: 1-40. 
Shahin, A. M. (1988): Fossil fauna and stable isotope composition within the Late Cretaceous-Early Tertiary at Gebel Nazzazat, Sinai, Egypt. Ph. D. Thesis, Geol. Dept. Fac. Sci., Mansura Uni., 212pp.

Shahin, A.M. (1992): Contribution to the foraminiferal biostratigraphy and paleobathymetry of the Late Cretaceous and Early Tertiary in west central Sinai, Egypt.Rev. Micropal. , 35: 157-175.

Shahin, A. M. (2001): Mass extinction and bioevents across the Paleocene-Eocene boundary in the western Sinai, Egypt. $N$. $J b$. Geol. Paläont.,Mh., 2001 (1) : 1-20.

Scheibner, C., Kuss, J. and Speijer, R. P., (2003): Stratigraphic modeling of carbonate plateform-to-basin sediments (Maastrichtian to Paleocene) in the Eastern Desert, Egypt.Paleogeog.Paleoclimat.Paleoecol., 3136: 1-23.

Sissingh, W., (1977): Biostratigraphy of Cretaceous calcareous nannoplankton.Geologie en. Mijnbouw, 56: 37-65.

Stainforth, R. M., Lamb, I. L., Luterbacher, H. P., Beard, I. H. and Jeffords, R. M. (1975): Cenozonic planktonic foraminiferal zonation and characteristics of index forms. Uni. Kansas Paleont. Contr. Art.Lawrence,62:1-425.

Soliman, M.F. and Obaidalla, N.A., (2006): Danian/Sealndian (D/S) boundary at Gabal Abu Had Section, Nile Valley (Egypt); lithostratigraphy, mineralogy, geochemistry and biostratigraphy. In: 6th International Conference on the Climate and Biota of the Early paleogene. Abstract, p. 125.

Speijer, R.P, Sprong, J., Youssef, M., Bornemann, A., Dupuis, C., Guasti, E., Morsi, M., Schule, P., Steurbaut, E., Van Itterbeek, J., Yans, J., (2007): Hurdles to take prior to decision complexity of biostratigraphy correlation of the Danian/Selandian transition between Zumaya, Denmark, Tunisia and Egypt. In:
International Workshop of the Paleocene Working Group (Zumaia, Basque Countary). Abstract, 31-34.

Sprong, J., Dupuis, C., Speijer, R.P., Steurbaut, E., Van Itterbeeck, J. and Yans, J., (2006): The Danian/Selandian transition in Tunisia: Paleoenvironment and sea level. In: 6th Intern. Conf. on the Climate and Biota of the Early paleogene. Abstract, p. 129.

Strougo, A. and Faris, M., (1993): Paleocene-Eocene stratigraphy of Wadi El Dakhla, Southern Galala Plateau. Middle East Research Center, Ain Shams Uni., 4962.

Tantawy, A.A., (1998): Stratigraphical and paleoecological studies on some PaleoceneEocene successions in Egypt.Unpub. Ph.D.Thesis, Assiut Uni., Egypt, 1-273.

Tantawy, A. A., (2003): Calcareous nannofossil biostratigraphy and paleoecology of the Cretaceous Tertiary transition in the central eastern desert of Egypt. Marine Micropaleontol. , 47: 323356.

Tantawy, A. A., (2006): Calcareous nannofossil of the Paleocene-Eocene transition at Qene Region, Central Nile Valley, Egypt.Micropaleontol. , 52(3): 193222.

Tantawy, A.A., Ouda, Kh., Salis, K. Von., and Saad El Din, M., (2000): Biostratigraphy of Paleocene sections. In: Schmitz, B., Sundquist, B. and Andreasson, F. (eds.), Early Paleogene warm climates and biosphere dynamics, GFF, 122:163-165. Tantawy, A.A., Keller, G., Adatte, T., Stinnesbeck, W., Kassab, A. and Schulte, P., (2001): Maastrichtian to Paleocene depositional environment of the Dakhla Formation, Western Desert, Egypt: sedimentology, mineralogy, and integrated micro- and macrofossil biostratigraphies. Cretaceous Research, 22: 95-827.

Thibault, N. and Gardin, S., (2006): Maastrichtian calcareous nannofossil 
biostratigraphy and paleoecology in the Equatorial Atlantic, Demerara Rise, ODP Leg 207 Hole 1258A. Rev. de Micropaleontol. , 49: 199-214.

Thierstein, H.R., (1976): Mesozoic nannoplankton biostratigraphy of marine sediments.-Marine Micropaleontol., 1: 325362.

Toumarkine, M. and Luterbacher, H., (1985): Paleocene and Eocene planktic foraminifera. In: Bolli, H. M., Saunders, J. B. and Perch-Nielsen, K. (eds.): Plankton Stratigraphy. Cambridge Uni. Press: 87-154. Verbeek, J.W. (1977): Calcareous nannoplankton biostratigraphy of Middle and Upper Cretaceous deposits in Tunisia, Southern Spain and France. Bull. Utrecgt Micropal., 16: 1-157.

Wade, B.S., Pearson, P.N., Berggren, W.A. and Pälike, H., (2011): Review and revision of Cenozoic tropical planktonic foraminiferal biostratigraphy and calibration to the geomagnetic polarity and astronomical time scale. Earth Sci. Rev., 104: 111-142.

Wind, F.H., (1979): MaastrichtianCampanian nannofloral provinces of the southern Atlantic and Indian Oceans. In: Talwani, M., et al. (Eds.): Deep Drilling Results in the Atlantic Ocean: Continental Margins and Paleoenvironment. Washington, Amer. Geophy. Union: 123137.

Youssef, M. I. And Abdelmalik, W. M. (1969): Micropaleontolgical zonation of the Tertiary Rocks of Tayiba-Feiran Area, West Central Sinai. 6th Arab.Sci.Congr.675-684; Damascus.

Youssef, M. I. (1957): Upper Cretaceous rocks in Kosseir area. Bulletin of the Institute of Desert, Egypt, 7: 35-54.

Ziko, A., Darwish, M., Eweda, S., (1993): Late CretaceouseEarly Tertiary stratigraphy ofthe Themed area, East Central Sinai, Egypt. Neues Jahrbuch für Geologie undPaläontologie, Monatshefte 13, 135e149.Geol.,101:191-213. 


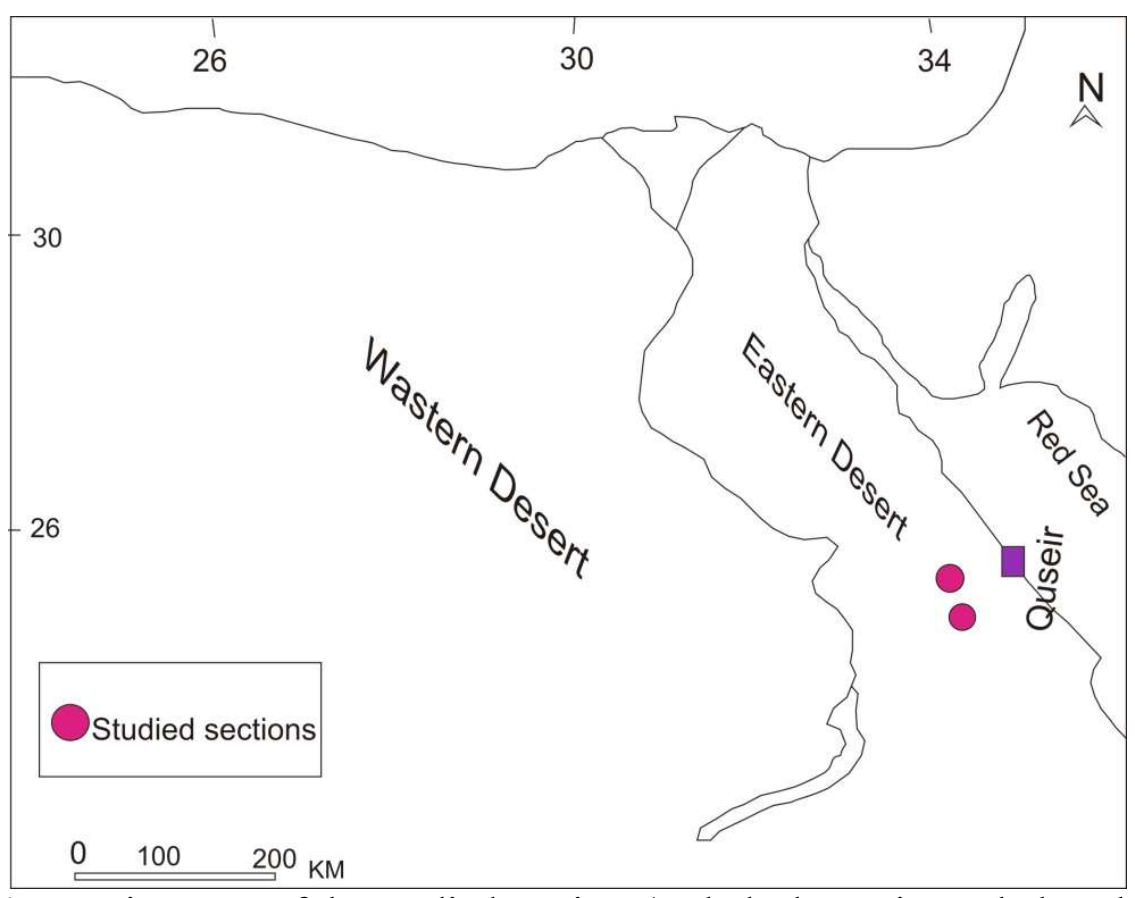

Fig 1.Location map of the studied sections(Gebel El Duwi \&Gebel Atshan).

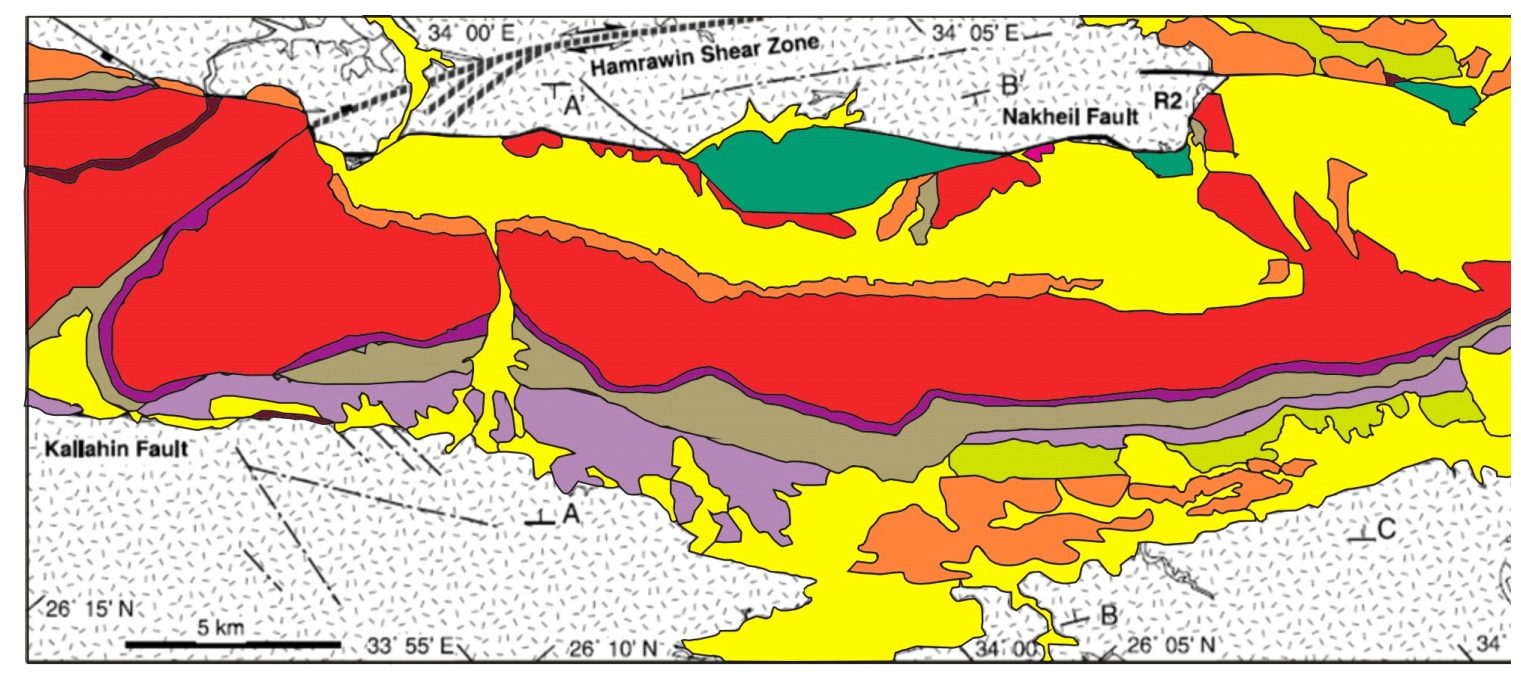

Fig . 2. Geologic map of the studied area, modified after Khalil\& Meclay (2002). 


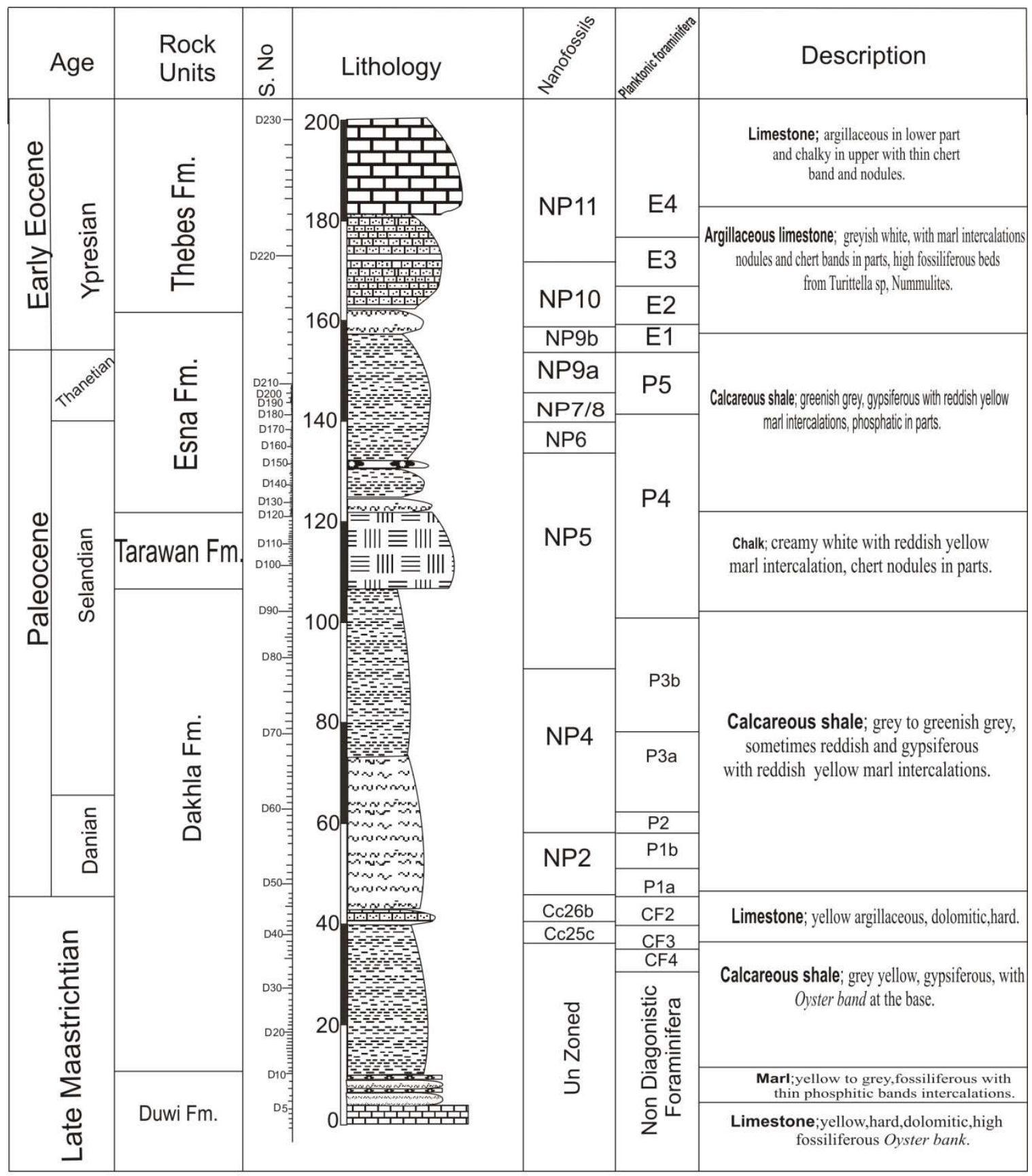

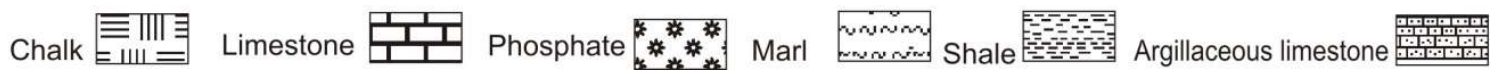

Fig. 3. Lithologic units, planktonic and calcareous nannofossil biozones of Upper Maastrichtian-Lower Eocene rocks of Gabel El Duwi. 


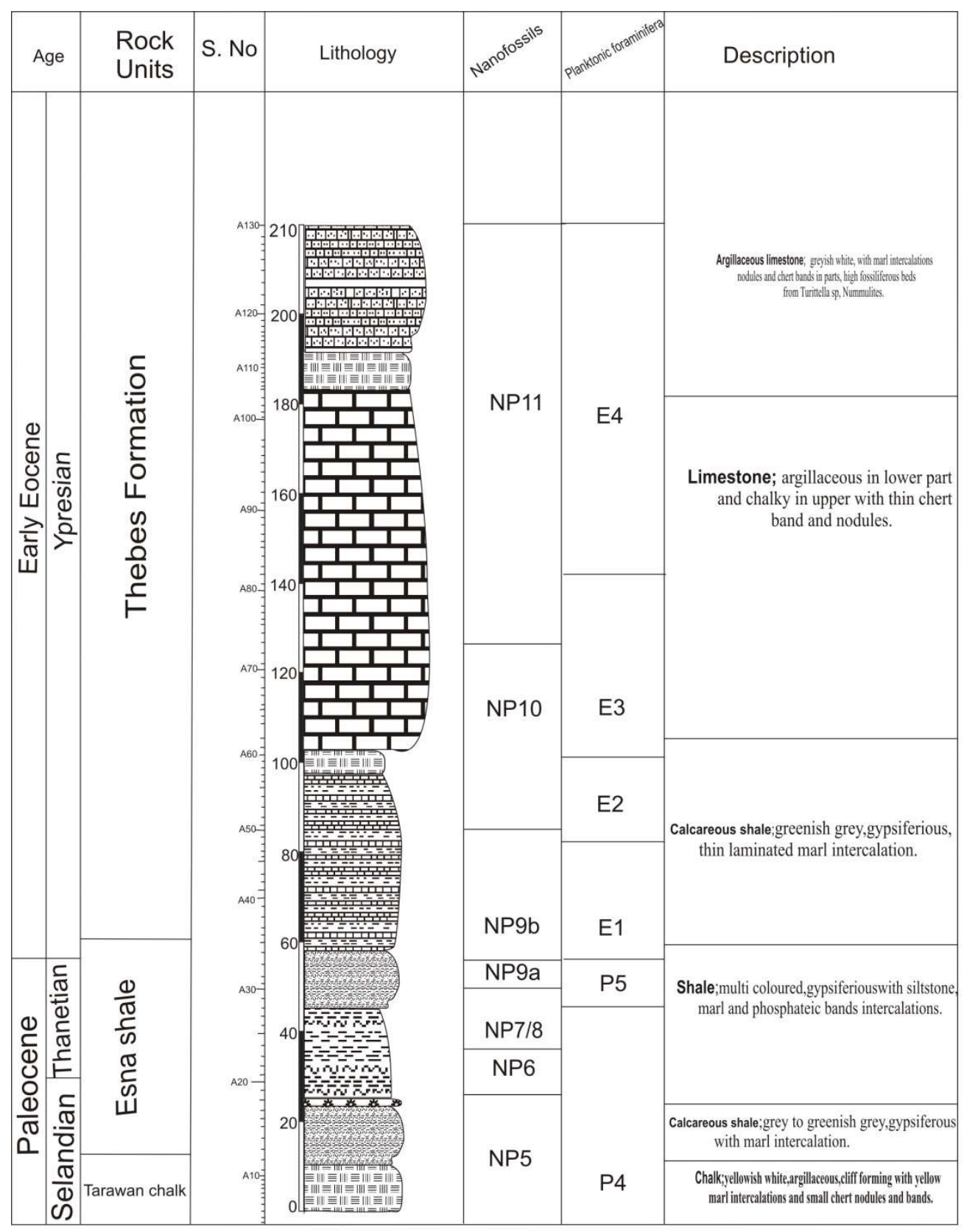

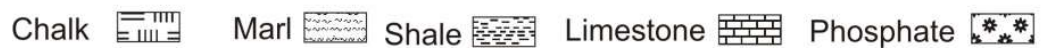

Fig. 4. Lithologic units, planktonic and calcareous nannofossil biozones of Upper Maastrichtian -Lower Eocene rocks of Gabel Atshan. 

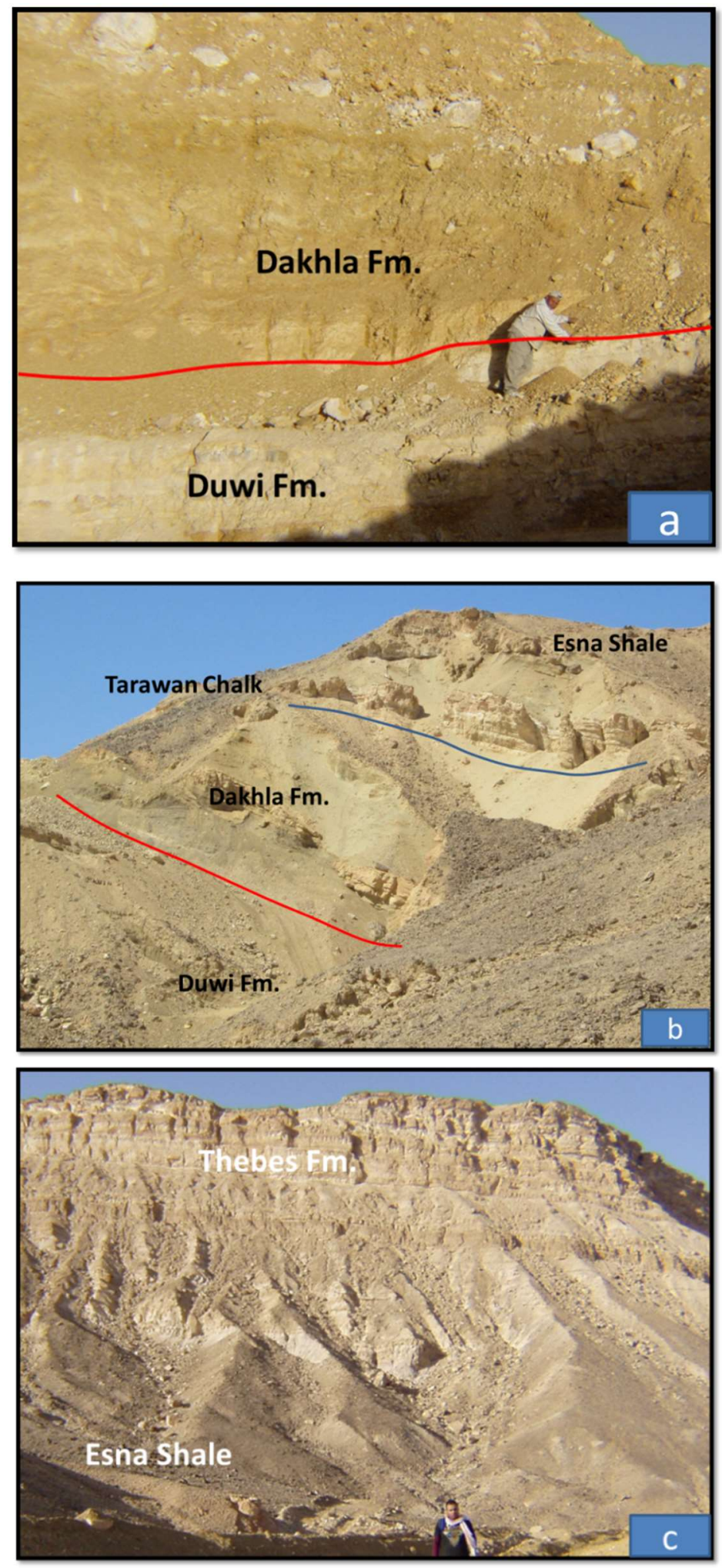

Fig. 5. a- Contact between Duwi Formation and Dakhla Shale at Gebel Duwi, b- Upper Cretaceous-Paleocene rock units in Gebel Duwi, c- Esna Shale and Thebes Formation at Gebel Duwi. 

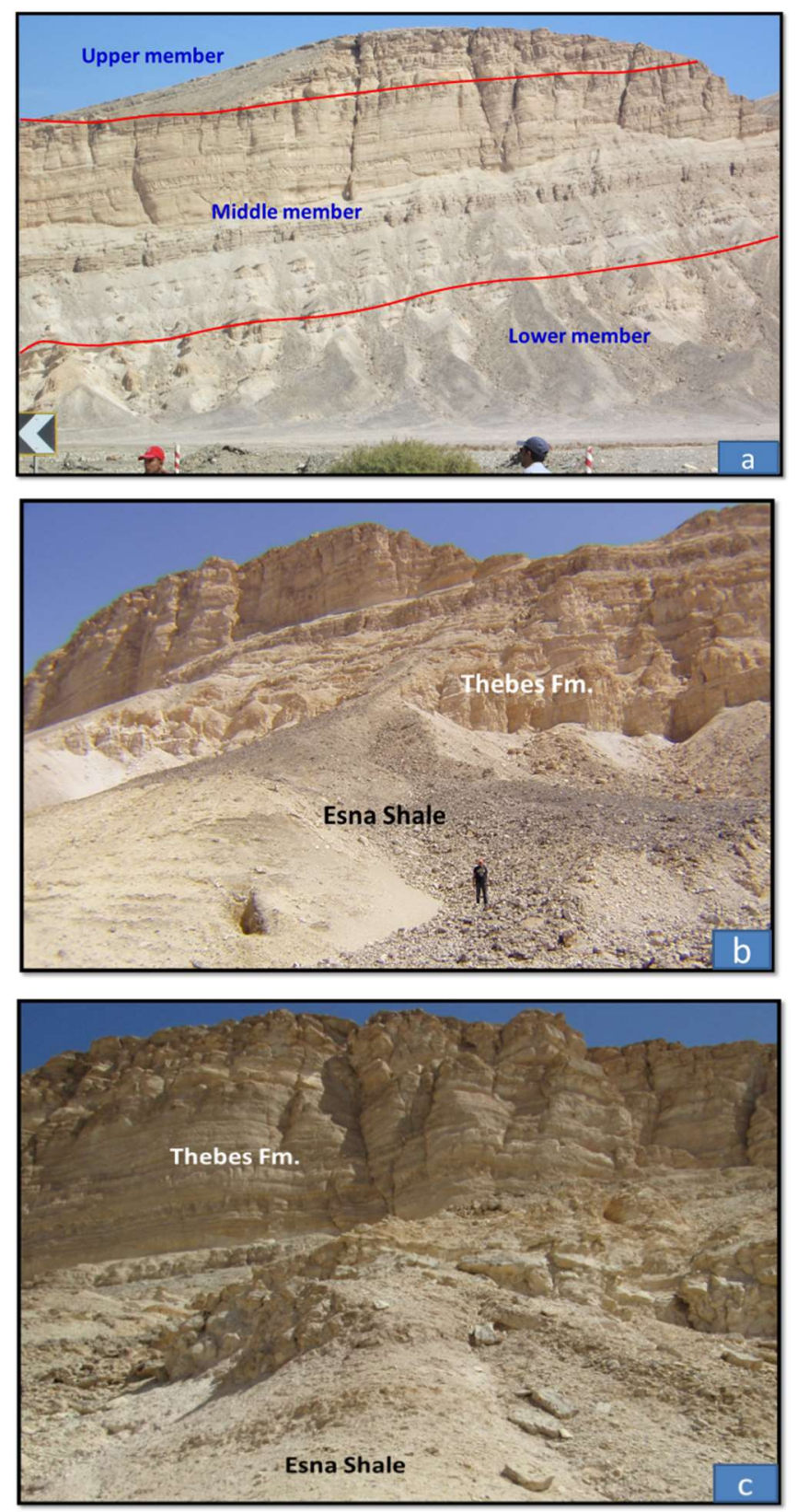

Fig. 6. a- Three informal members of the Thebes formation at Gebel Atshan Section, bEsna Shale and Thebes Formations at Gebel Atshan, c, Gradational contact between Esna and Thebes formations at Gebel Atshan Section.

Plate 1 


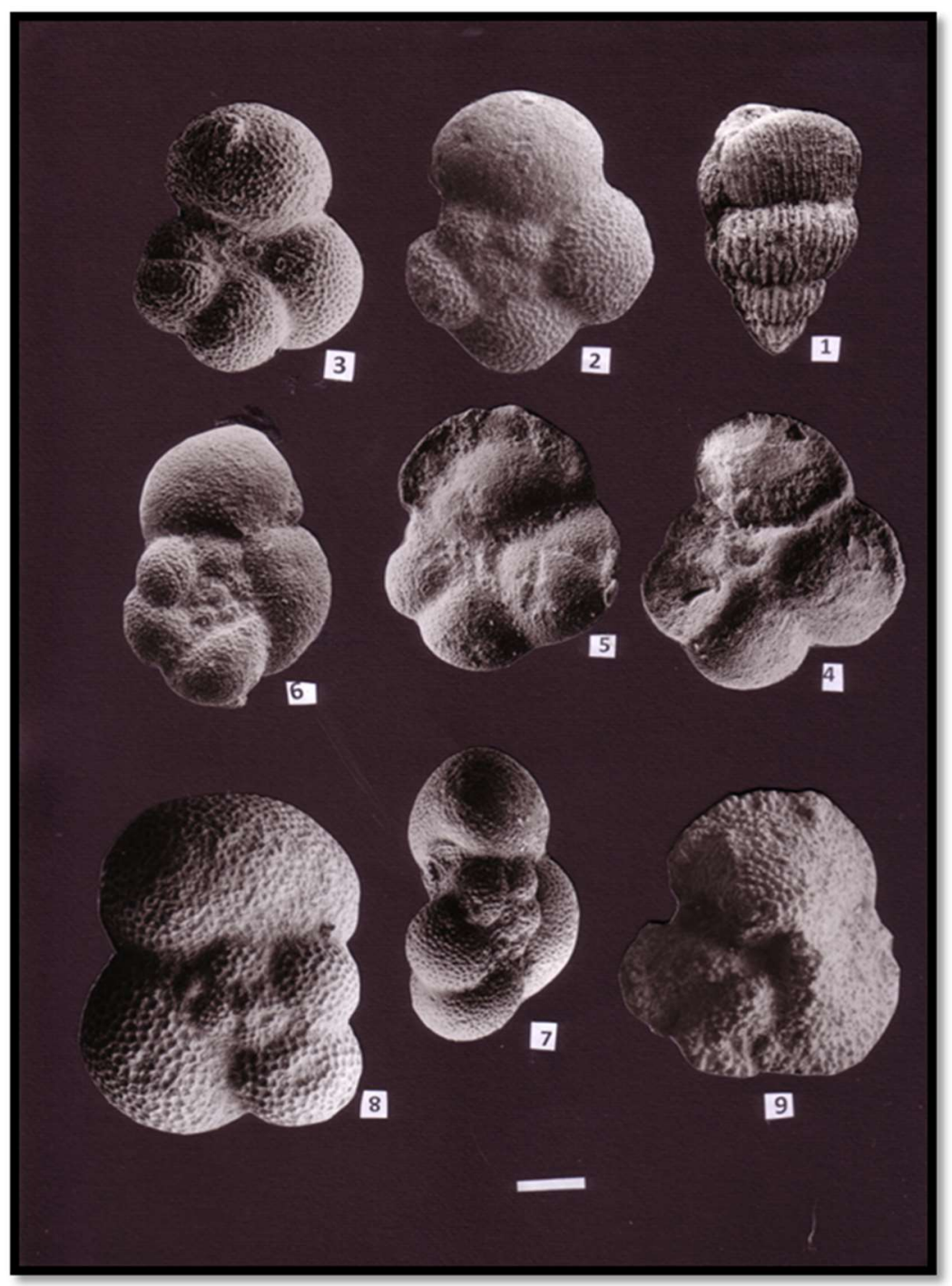

Scale bar is $100 \mu \mathrm{m}$.

Plate 1: 1- Pseudotextularia deformis (Kikoine), sample D3, Duwi Formation. 2, 3Parasubbotina pseudbulloides (Plummer), sample D25, Dakhla Formation. 4, 5Globanomalina pseudominardii (Bolli), sample D60, Dakhla Formation. 6, 7Globanomalina compressa (Plummer), sample D70, Dakhla Formation. 8- Subbotina triloculinoides (Plummer), sample D50, Esna Formation. 9- Morozovella subbotinae (Morozova), sample D140, Esna Formation.

Plate 2 


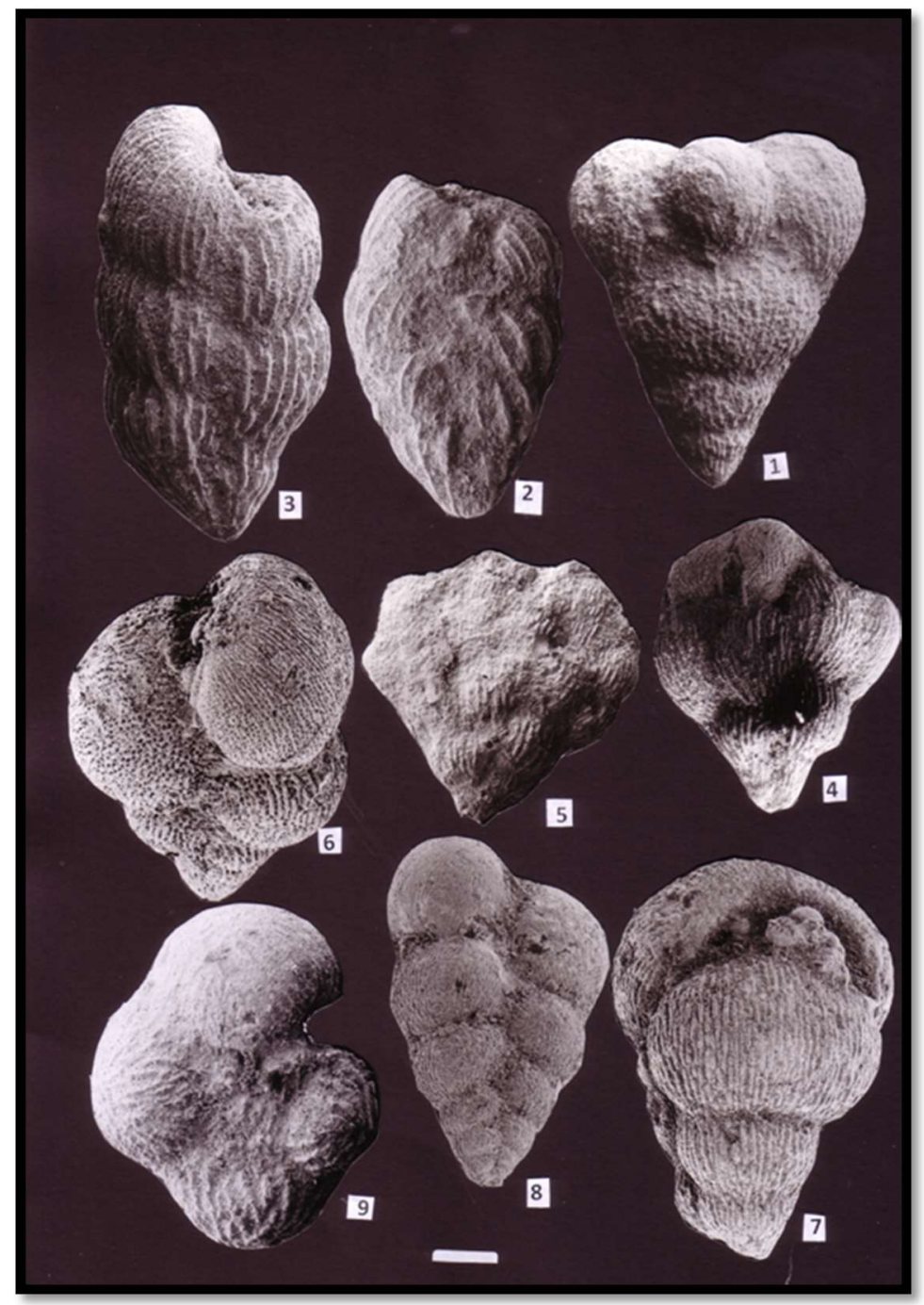

Scale bar is $100 \mu \mathrm{m}$.

Plate 2. 1- Racemiguembelina fructicosa (Egger), sample D9, Duwi Formation. 2, 3Pseudoguembelina costulata (Cushman), sample D5, Duwi Formation. 4Pseudoguembelina hariaensis Nederbragt, sample D32, Dakhla Formation. 5Pseudoguembelina sp., sample D20, Dakhla Formation 6,7- Pseudoguembelina palpebral Bronnimann, sample D8, Duwi Formation. 8- Heterohelix globulasa Ehrenberg, sample D10, Duwi Formation. 9- Rugoglobigerina rugosa Plummer, sample D72, Dakhla Formation. 


\section{Plate 3}

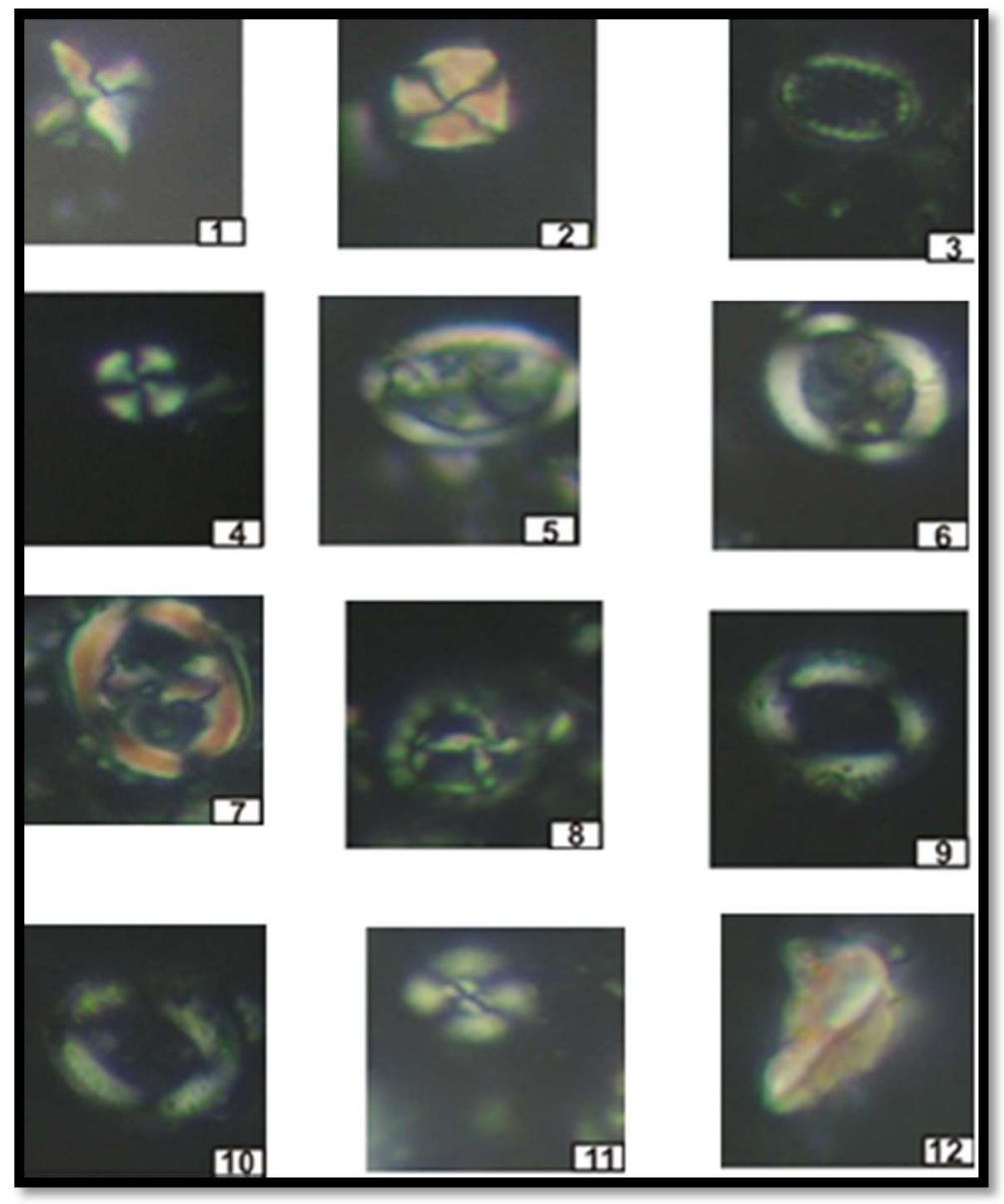

\section{Scale bar is $10 \mu \mathrm{m}$.}

Plate 3. 1- Micula decussataVekshina (1959). Sample D4, Duwi Formation. 2- Micula murus (Martini, 1961) Samples D6 ,Duwi Formation.3- Cribrosphaerella ehrenbergii (Arkhangelsky, 1912) Sample D5, Duwi Formation. 4,11- Watznaueria barnesae (Black in Black \& Barnes, 1959), Sample D6, Duwi Formation. 5,6- Arkhangelskiella cymbiformis Vekshina (1959), Samples D7, Duwi Formation.7- Zeugrhabdotus embergeri (Noel, 1959), Sample D9, Duwi Formation. 8- Prediscosphaera grandis Perch-Nielsen (1979) Samples D6, Duwi Formation. 9, 10- Manivitella pemmatoidea (Deflandre in Manivit, 1965) Samples D8, Duwi Formation. 12- Lucianorhabdus cayeuxii Deflandre (1959), Sample D6, Duwi Formation.

\section{Plate 4}




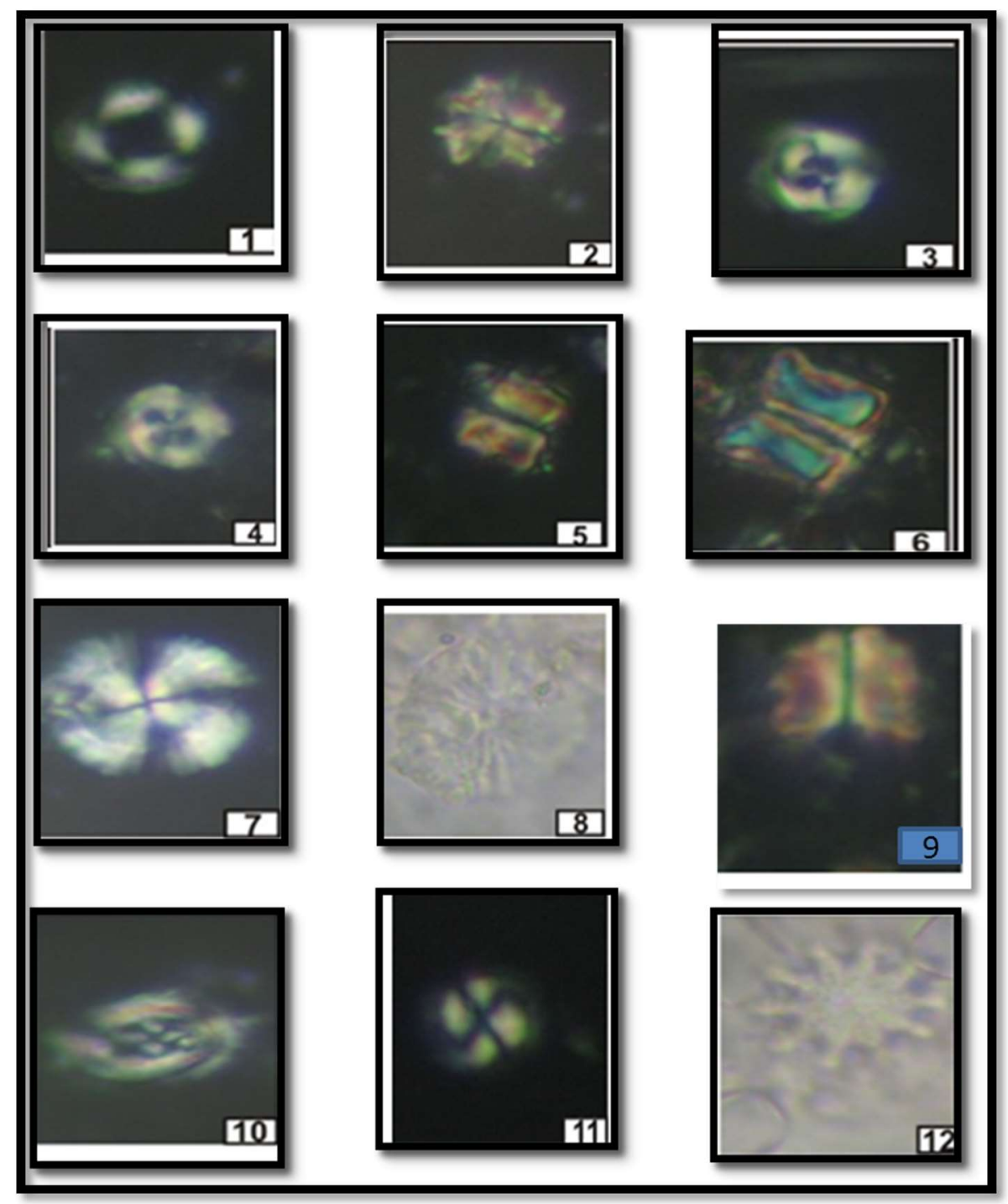

Scale bar is $10 \mu \mathrm{m}$.

Plate: 4.1- Ericsonia cfuniversa Wind and Wise (1977), Sample 40, Dakhla Formation. 2- Sphenolithus primus (Bramlette \& Sullivan, 1961), Sample D70, Dakhla Formation. 3,4- Toweiuse minens (Bramlette \& Sullivan, 1961) Sample D99, Esna Formation. 5, 9Fasciculithus tympaniforms Hay \& Mohler in Hay et al. (1967) Sample D44, Dakhla Formation. 6- Fasciculithus involutus Bramlette \& Sullivan (1961) Sample 31, Dakhla Formation. 7Heliolithus cantabriae Perch-Nielsen (1971) Sample 72, Esna Formation. .8Discoasterm ultiradiatus Bramlette \&
Reidel (1954 ) D140-D171,Esna Formation.10-Cruciplacolithus tenuis (Stradner, 1961) Hay \& Mohler in Hay et al. (1967), Sample D124, Esna Formation. 11- Ericsonia subpertusa (1967) Sample D158, Esna Formation. 2- Discoaster binodosus (Martini,1958) Sample D173, Esna Formation. 